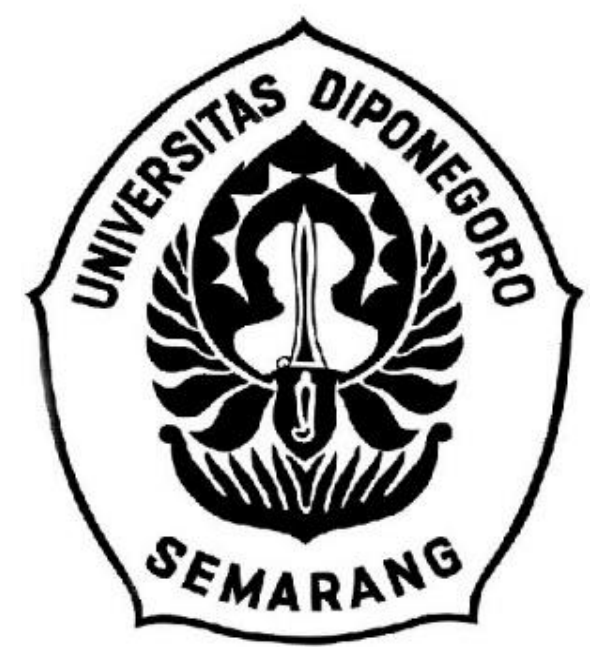

\title{
LAMPIRAN
}




\section{Lampiran A}

Form Kuesioner Tahap Pertama (Kuesioner Pendahuluan) 


\begin{tabular}{|c|c|c|c|c|c|}
\hline \multirow{2}{*}{\multicolumn{6}{|c|}{$\begin{array}{l}\text { KUESIONER ANALISIS RISIKO PEKERJAAN PERPANJANGAN DERMAGA LOG } \\
\text { PELABUHAN TANJUNG EMAS }\end{array}$}} \\
\hline & & & & & \\
\hline \multicolumn{6}{|c|}{ (Kuesioner Tahap 1 Konsultan) } \\
\hline \multicolumn{6}{|c|}{ Data Responden } \\
\hline 1 & Nama & :................. & & & \\
\hline 2 & Usia & :................ thn & & & \\
\hline 3 & Posisi & :.................. & & & \\
\hline \multicolumn{2}{|c|}{ Petunjuk } & & & & \\
\hline \multicolumn{6}{|c|}{ Mohon pengisian kuisioner untuk setiap pernyataan/pertanyaan dapat dijawab sesuai kenyataan yang ada di lapangan. } \\
\hline \multicolumn{5}{|c|}{ Kolom RELEVAN dapat diisi, jika variabel risiko berkaitan dengan proyek yang dilaksanakan. } & \\
\hline \multicolumn{6}{|c|}{ Kolom TIDAK RELEVAN dapat diisi, jika variabel risiko tidak memiliki keterkaitan dengan proyek yang dilaksanakan. } \\
\hline No & Variabel & Indikator & Kode & RELEVAN & $\begin{array}{l}\text { TIDAK } \\
\text { RELEVAN }\end{array}$ \\
\hline \multirow{3}{*}{1} & \multirow{3}{*}{ Risiko Alam } & $\begin{array}{l}\text { Cuaca Ekstrim (Hujan lebat, gelombang tinggi, angin } \\
\text { kencang, dan petir) }\end{array}$ & $\mathrm{R} 1$ & & \\
\hline & & Force majeur (banjir, kebakaran, dan gempa bumi) & $\mathrm{R} 2$ & & \\
\hline & & Pasang surut air laut & R3 & & \\
\hline \multirow[t]{2}{*}{2} & \multirow[t]{2}{*}{ Risiko Ekonomi } & $\begin{array}{l}\text { Inflasi nilai mata uang yang dapat menyebabkan } \\
\text { kenaikan harga }\end{array}$ & $\mathrm{R} 4$ & & \\
\hline & & Perubahan kebijakan harga BBM & R5 & & \\
\hline \multirow{4}{*}{3} & \multirow{4}{*}{$\begin{array}{l}\text { Risiko } \\
\text { Lingkungan }\end{array}$} & Kondisi tanah yang tidak stabil & R6 & & \\
\hline & & \begin{tabular}{|l}
$\begin{array}{l}\text { Gangguan akan adanya aktivitas bongkar muat } \\
\text { barang }\end{array}$ \\
\end{tabular} & $\mathrm{R} 7$ & & \\
\hline & & $\begin{array}{ll}\begin{array}{l}\text { Instansi/Perusahaan sekitar proyek yang kurang } \\
\text { mendukung }\end{array} & \\
\end{array}$ & $\mathrm{R} 8$ & & \\
\hline & & Pencemaran ekosistem laut dan udara & R9 & & \\
\hline \multirow{4}{*}{4} & \multirow{4}{*}{$\begin{array}{l}\text { Risiko SDM \& } \\
\text { Manajemen }\end{array}$} & $\begin{array}{l}\text { Adanya kesalahpahaman antar stakeholder yang } \\
\text { disebabkan kurangnya komunikasi/koordinasi }\end{array}$ & R10 & & \\
\hline & & Ketidakdisiplian personil & R11 & & \\
\hline & & $\begin{array}{l}\text { Pemahaman personil yang kurang tentang konstruksi } \\
\text { dermaga }\end{array}$ & R12 & & \\
\hline & & Perubahan struktur organisasi dari pihak owner & R13 & & \\
\hline \multirow{2}{*}{5} & \multirow{2}{*}{ Risiko Finansial } & Keterlambatan pembayaran & R14 & & \\
\hline & & Kurangnya dana finansial dari owner & R15 & & \\
\hline \multirow{4}{*}{6} & \multirow{4}{*}{ Risiko Teknis } & Ketidakpahaman pada dokumen kontrak \& RKS & R16 & & \\
\hline & & Keterlambatan proses administrasi dan perizinan & R17 & & \\
\hline & & Perubahan desain akbiat perubahan kondisi lapangan & R18 & & \\
\hline & & Desain yang tidak lengkap & R19 & & \\
\hline \multirow{6}{*}{7} & \multirow{6}{*}{ Risiko Proyek } & Kecelakaan kerja saat proyek berlangsung & $\mathrm{R} 20$ & & \\
\hline & & Ketidaktepatan lokasi pemancangan & $\mathrm{R} 21$ & & \\
\hline & & Adanya keretakan pada struktur & R22 & & \\
\hline & & Ketidaksepahaman metode kerja dengan kontraktor & $\mathrm{R} 23$ & & \\
\hline & & Kesalahan pemeriksaan volume saat opname & $\mathrm{R} 24$ & & \\
\hline & & Pergeseran dermaga eksisting & $\mathrm{R} 25$ & & \\
\hline \multirow{2}{*}{8} & \multirow{2}{*}{ Risiko .......... } & Risiko lainnya............. & $\ldots \ldots$ & & \\
\hline & & Risiko lainnya............ & ...... & & \\
\hline
\end{tabular}




\begin{tabular}{|c|c|c|c|c|c|}
\hline \multicolumn{6}{|c|}{ KUESIONER ANALISIS RISIKO PEKERJAAN PERPANJANGAN DERMAGA LOG } \\
\hline \multicolumn{6}{|c|}{ PELABUHAN TANJUNG EMAS } \\
\hline \multicolumn{6}{|c|}{ (Kuesioner Tahap 1 Kontraktor) } \\
\hline & & & & & \\
\hline \multicolumn{6}{|c|}{ Data Responden } \\
\hline 1 & Nama & $: \ldots \ldots \ldots \ldots \ldots \ldots$ & & & \\
\hline 2 & Usia & $: \ldots \ldots \ldots \ldots \ldots$ thn & & & \\
\hline 3 & Posisi & $: \ldots \ldots \ldots \ldots \ldots \ldots$ & & & \\
\hline & & & & & \\
\hline \multicolumn{2}{|c|}{ Petunjuk } & & & & \\
\hline \multicolumn{6}{|c|}{ Mohon pengisian kuisioner untuk setiap pernyataan/pertanyaan dapat dijawab sesuai kenyataan yang ada di lapangan. } \\
\hline \multirow{2}{*}{\multicolumn{6}{|c|}{$\begin{array}{l}\text { Kolom RELEVAN dapat diisi, jika variabel risiko berkaitan dengan proyek yang dilaksanakan. } \\
\text { Kolom TIDAK RELEVAN dapat diisi, jika variabel risiko tidak memiliki keterkaitan dengan proyek yang dilaksanakan. }\end{array}$}} \\
\hline & & & & & \\
\hline & & & & & \\
\hline No & Variabel & Indikator & Kode & RELEVAN & $\begin{array}{l}\text { TIDAK } \\
\text { RELEVAN }\end{array}$ \\
\hline \multirow{3}{*}{1} & \multirow{3}{*}{ Risiko Alam } & $\begin{array}{l}\text { Cuaca Ekstrim (Hujan lebat, gelombang tinggi, angin } \\
\text { kencang, dan petir) }\end{array}$ & $\mathrm{R} 1$ & & \\
\hline & & Force majeur (banjir, kebakaran, dan gempa bumi) & $\mathrm{R} 2$ & & \\
\hline & & Pasang surut air laut & $\mathrm{R} 3$ & & \\
\hline \multirow[t]{2}{*}{2} & \multirow[t]{2}{*}{ Risiko Ekonomi } & $\begin{array}{l}\text { Inflasi nilai mata uang yang dapat menyebabkan } \\
\text { kenaikan harga }\end{array}$ & $\mathrm{R} 4$ & & \\
\hline & & Perubahan kebijakan harga BBM & R5 & & \\
\hline \multirow{5}{*}{3} & \multirow{5}{*}{ Risiko Lingkungan } & Kondisi tanah yang tidak stabil & R6 & & \\
\hline & & Gangguan akan adanya aktivitas bongkar muat barang & R7 & & \\
\hline & & $\begin{array}{|llll|}\begin{array}{l}\text { Instansi/Perusahaan } \\
\text { mendukung }\end{array} & \text { sekitar proyek yang kurang } \\
\end{array}$ & $\mathrm{R} 8$ & & \\
\hline & & Pencemaran ekosistem laut dan udara & R9 & & \\
\hline & & Kebisingan suara & $\mathrm{R} 10$ & & \\
\hline \multirow{6}{*}{4} & \multirow{6}{*}{$\begin{array}{l}\text { Risiko SDM \& } \\
\text { Manajemen }\end{array}$} & $\begin{array}{l}\text { Adanya } \text { double job pada personil sehingga mengurangi } \\
\text { fokus personil untuk menyelesaikan satu } \\
\text { tugas/pekerjaan }\end{array}$ & R11 & & \\
\hline & & $\begin{array}{l}\text { Perselisihan atau koordinasi yang buruk antar tenaga } \\
\text { kerja }\end{array}$ & $\mathrm{R} 12$ & & \\
\hline & & Keahlian tenaga kerja yang kurang & $\mathrm{R} 13$ & & \\
\hline & & Produktivitas pekerja yang rendah & R14 & & \\
\hline & & Adanya kesalahanpahaman antara stakeholder & R15 & & \\
\hline & & Perubahan struktur organisasi dari pihak owner & R16 & & \\
\hline \multirow{9}{*}{5} & \multirow{9}{*}{ Risiko Finansial } & Keterlambatan pembayaran & R17 & & \\
\hline & & Kurangnya dana finansial dari owner & R18 & & \\
\hline & & Penambahan biaya pengangkutan material & R19 & & \\
\hline & & $\begin{array}{l}\text { Penambahan biaya mobilisasi \& demobilisasi alat baru } \\
\text { dikarenakan kesalahan metode kerja }\end{array}$ & $\mathrm{R} 20$ & & \\
\hline & & Penambahan jam kerja/lembur & $\mathrm{R} 21$ & & \\
\hline & & Kehilangan volume material pada pengangkutan & R22 & & \\
\hline & & Kerusakan material pada pengangkutan & $\mathrm{R} 23$ & & \\
\hline & & Kecelakaan yang terjadi saat pengangkutan & R24 & & \\
\hline & & Ketidaktepatan estimasi waktu dan biaya & $\mathrm{R} 25$ & & \\
\hline \multirow{4}{*}{6} & \multirow{4}{*}{ Risiko Teknis } & Ketidakpahaman pada dokumen kontrak \& RKS & $\mathrm{R} 26$ & & \\
\hline & & Keterlambatan proses administrasi dan perizinan & R27 & & \\
\hline & & Perubahan desain akbiat perubahan kondisi lapangan & $\mathrm{R} 28$ & & \\
\hline & & Desain yang tidak lengkap & R29 & & \\
\hline
\end{tabular}




\begin{tabular}{|c|c|c|c|c|c|}
\hline \multirow{10}{*}{7} & \multirow{10}{*}{ Risiko Proyek } & Kecelakaan kerja saat proyek berlangsung & R30 & & \\
\hline & & Ketidaktepatan lokasi pemancangan & R31 & & \\
\hline & & Adanya keretakan pada struktur & $\mathrm{R} 32$ & & \\
\hline & & Kesulitan penggunaan teknologi baru & R33 & & \\
\hline & & Pergeseran dermaga eksisting & R34 & & \\
\hline & & Metode pelaksanaan yang tidak tepat & R35 & & \\
\hline & & Kerusakan alat berat saat pelaksanaan pekerjaan & R36 & & \\
\hline & & Pengadaan material yang tidak sesuai spesifikasi & R37 & & \\
\hline & & Pengadaan material yang tidak sesuai jadwal & R38 & & \\
\hline & & $\begin{array}{l}\text { Terhambatnya pengangkatan dan penurunan alat dan } \\
\text { material (loading dan unloading) }\end{array}$ & R39 & & \\
\hline \multirow[b]{2}{*}{8} & \multirow{2}{*}{ Risiko .......... } & Risiko lainnya............. & & & \\
\hline & & Risiko lainnya........... & & & \\
\hline
\end{tabular}




\section{Lampiran B}

Form Kuesioner Tahap Kedua (Kuesioner Utama) 


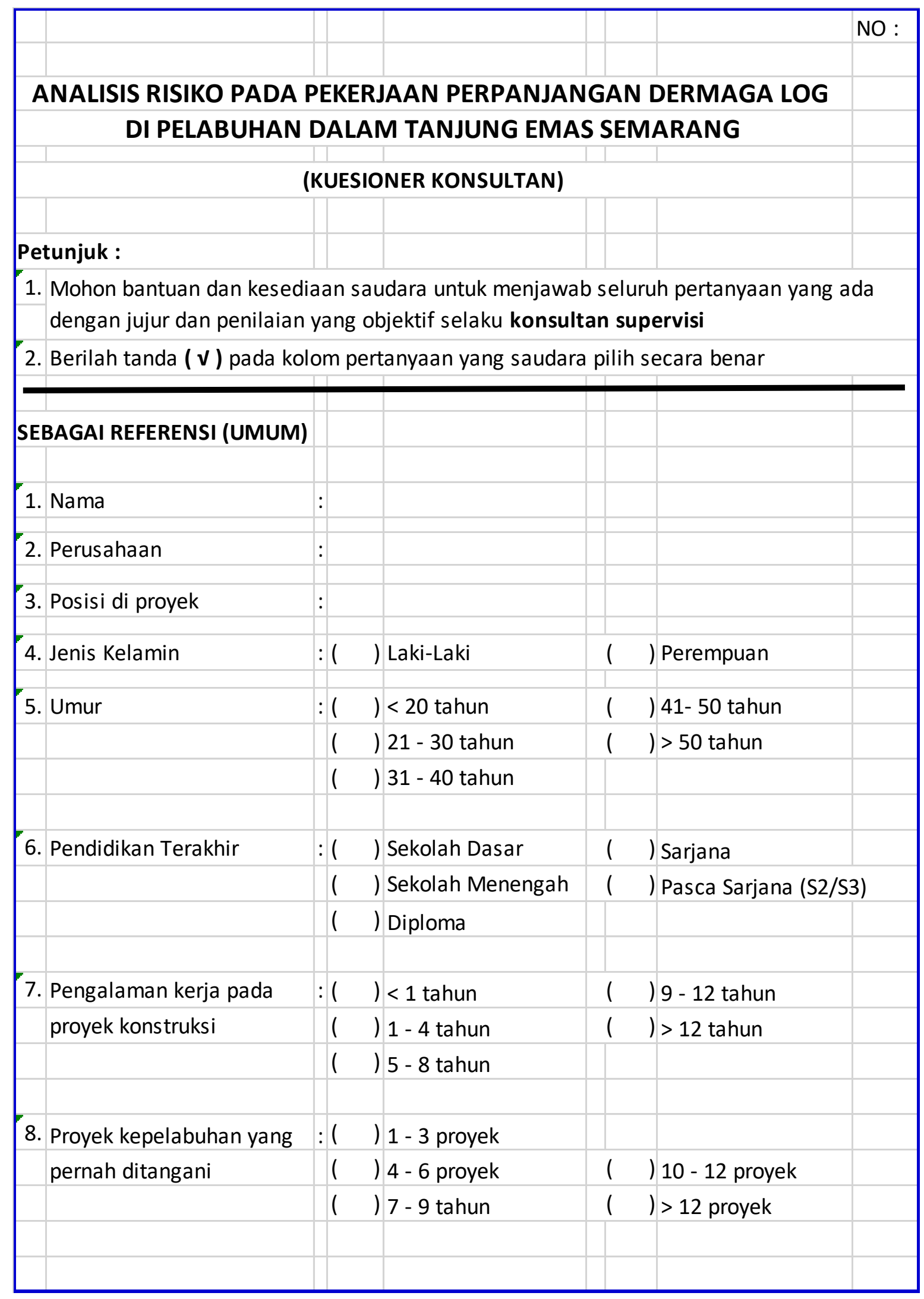




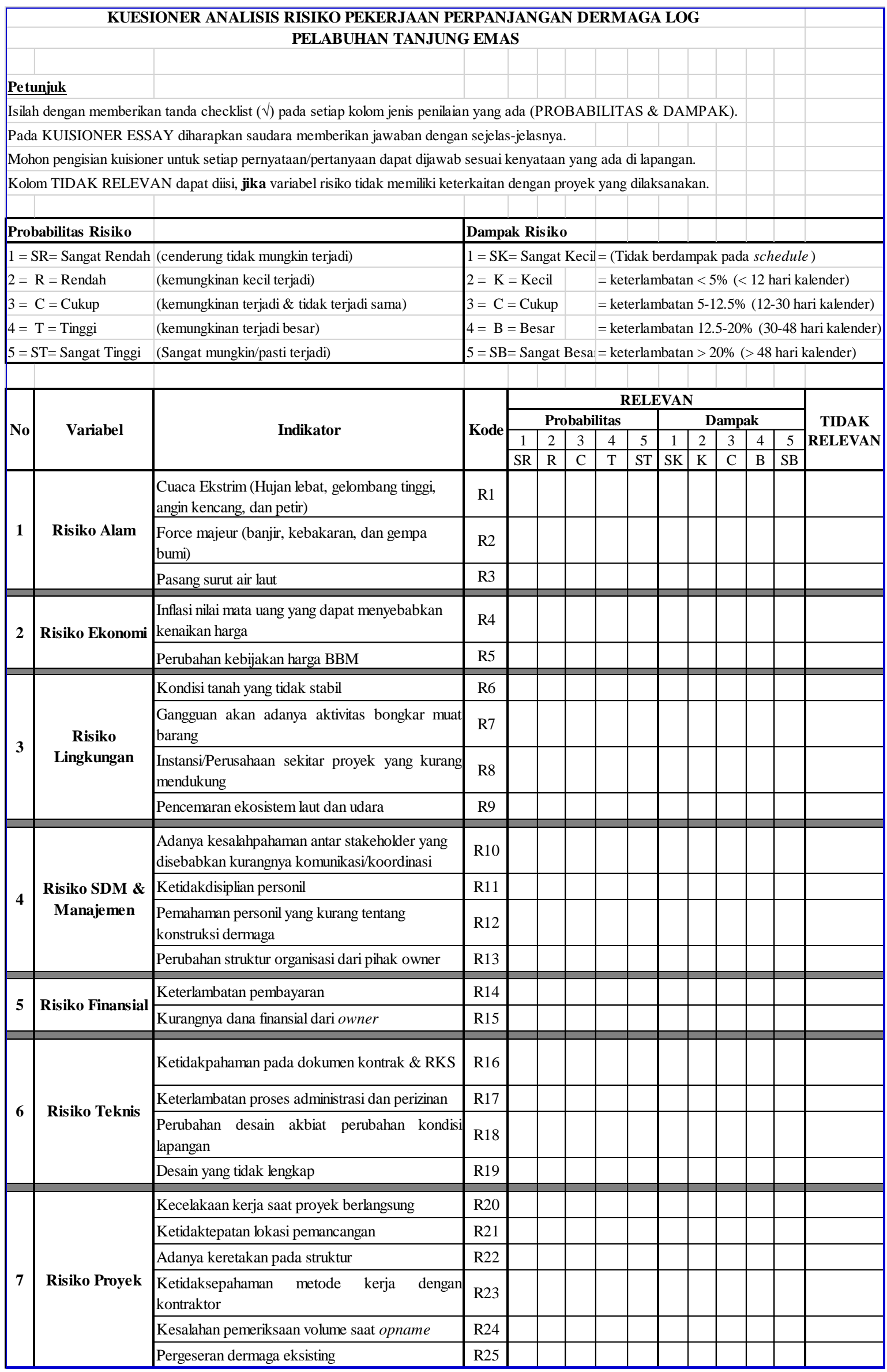




\section{KUESIONER ESSAY}

1 Dari beberapa risiko di atas, manakah yang dampaknya paling merugikan bagi proyek anda? Berikan alasannya! Dan bagaimana cara penanganannya menurut anda ? (boleh lebih dari 1 risiko)

Risiko yang dampaknya paling merugikan :

Alasan :

Cara penanganan :

2 Dari beberapa risiko di atas, manakah risiko yang paling sering terjadi pada proyek anda? Berikan alasannya! Dan bagaimana cara penanganannya menurut anda? (boleh lebih dari 1 risiko)

Risiko yang paling sering terjadi :...

Alasan :

Cara penanganan :

Car

3 Dari beberapa risiko di atas, manakah risiko yang signifikan (paling sering terjadi dan berdampak paling besar) pada proyek anda? Berikan alasannya! Dan bagaimana cara penanganannya menurut anda ?(boleh lebih dari 1 risiko) Risiko yang signifikan :

Alasan :

Alasan :...........................................................

Cara penanganan :

4 Berapa lama maksimal keterlambatan waktu yang diperbolehkan terjadi jika dilihat dari sudut pandang anda selaku konsultan pengawas? (dapat dijawab dalam satuan hari)

Jawaban :

Apa alasan/pertimbangan yang menyebabkan keterlambatan dalam kurun waktu tersebut masih diperbolehkan? Jawaban :

5 Jika dilihat dari lingkup pekerjaan yang ada, apa kegiatan/pekerjaan yang paling berpotensi mempengaruhi atau menyebabkan keterlambatan waktu pada pelaksanaan Perpanjangan Dermaga Log ? (boleh lebih dari 1 pekerjaan) Jawaban :

Alasan : 


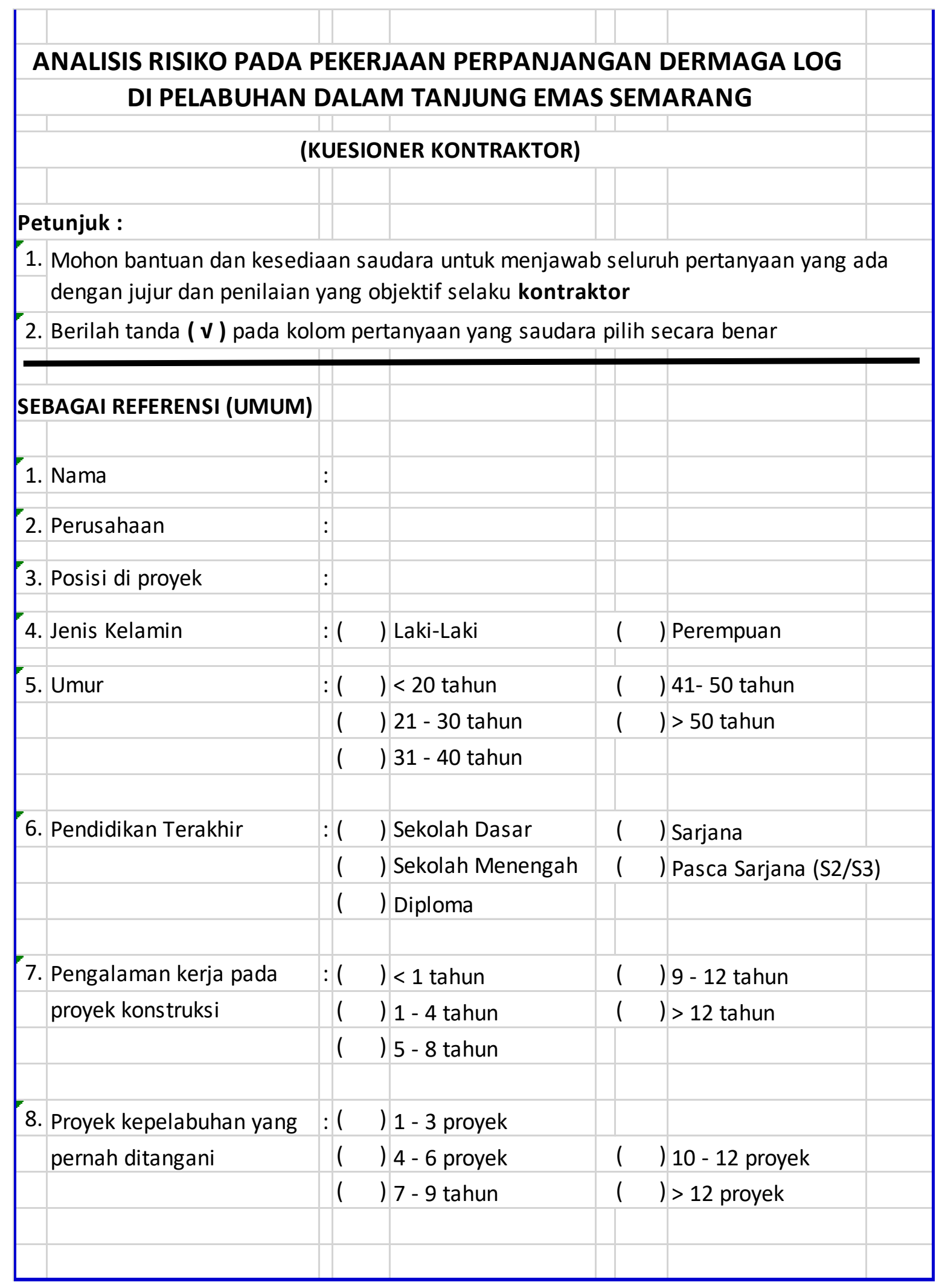




\begin{tabular}{|c|c|c|c|c|c|c|c|c|c|c|c|c|c|c|}
\hline \multicolumn{15}{|c|}{ KUESIONER ANALISIS RISIKO PEKERJAAN PERPANJANGAN DERMAGA LOG } \\
\hline \multicolumn{15}{|c|}{ PELABUHAN TANJUNG EMAS } \\
\hline & & & & & & & & & & & & & & \\
\hline \multicolumn{2}{|c|}{ Petunjuk } & & & & & & & & & & & & & \\
\hline \multicolumn{12}{|c|}{ 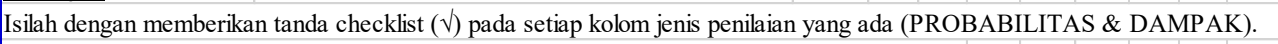 } & & & \\
\hline \multicolumn{7}{|c|}{ Pada KUISIONER ESSAY diharapkan saudara memberikan jawaban dengan sejelas-jelasnya. } & & & & & & & & \\
\hline \multicolumn{11}{|c|}{ Mohon pengisian kuisioner untuk setiap pernyataan/pertanyaan dapat dijawab sesuai kenyataan yang ada di lapangan. } & & & & \\
\hline \multicolumn{11}{|c|}{ Kolom TIDAK RELEVAN dapat diisi, jika variabel risiko tidak memiliki keterkaitan dengan proyek yang dilaksanakan. } & & & & \\
\hline & & & & & & & & & & & & & & \\
\hline \multicolumn{2}{|c|}{ Probabilitas Risiko } & & \multicolumn{4}{|c|}{ Dampak Risiko } & & & & & & & & \\
\hline \multicolumn{3}{|c|}{$1=\mathrm{SR}=$ Sangat Rendah (cenderung tidak mungkin terjadi) } & \multicolumn{12}{|c|}{$1=\mathrm{SK}=$ Sangat Kecil $=($ Tidak berdampak pada schedule $)$} \\
\hline \multicolumn{2}{|c|}{$2=\mathrm{R}=$ Rendah } & (kemungkinan kecil terjadi) & \multicolumn{4}{|c|}{$2=\mathrm{K}=$ Kecil } & \multicolumn{8}{|c|}{$=$ keterlambatan $<5 \%(<12$ hari kalender $)$} \\
\hline \multicolumn{2}{|c|}{$3=\mathrm{C}=$ Cukup } & (kemungkinan terjadi \& tidak terjadi sama) & \multicolumn{4}{|c|}{$3=\mathrm{C}=$ Cukup } & \multicolumn{8}{|c|}{$=$ keterlambatan 5-12.5\% (12-30 hari kalender) } \\
\hline $4=$ & $\mathrm{T}=$ Tinggi & (kemungkinan terjadi besar) & $4=B$ & $=\mathrm{Bes}$ & & & $=\mathrm{ket}$ & terlam & batan & n 12 . & $5-20$ & $7(30$ & $0-48 \mathrm{~h}$ & ari kalender) \\
\hline $5=S$ & $\mathrm{ST}=$ Sangat Tinggi & (Sangat mungkin/pasti terjadi) & $5=\mathrm{SB}$ & $=$ San & gat $\mathrm{I}$ & Besa & $1=\mathrm{ket}$ & terlam & ibatan & $n>2$ & $0 \%($ & $>48$ & hari $\mathrm{k}$ & kalender) \\
\hline & & & & & & & & & & & & & & \\
\hline & & & & & & & & RELE & EVAN & & & & & \\
\hline & & & & & Pro & babi & ilitas & & & & amp & & & TIDAK \\
\hline No & Variabel & Indikator & Kode & 1 & 2 & 3 & 4 & 5 & 1 & 2 & 3 & 4 & 5 & RELEVAN \\
\hline & & & & \begin{tabular}{|l|l|} 
SR \\
\end{tabular} & $\mathrm{R}$ & $\mathrm{C}$ & $\mathrm{T}$ & ST & SK & $\mathrm{K}$ & $\mathrm{C}$ & $\mathrm{B}$ & SB & \\
\hline & & $\begin{array}{l}\text { Cuaca Ekstrim (Hujan lebat, gelombang tinggi, angin } \\
\text { kencang, dan petir) }\end{array}$ & $\mathrm{R} 1$ & & & & & & & & & & & \\
\hline 1 & Risiko Alam & Force majeur (banjir, kebakaran, dan gempa bumi) & $\mathrm{R} 2$ & & & & & & & & & & & \\
\hline & & Pasang surut air laut & R3 & & & & & & & & & & & \\
\hline 2 & Risiko Ekonomi & $\begin{array}{l}\text { Inflasi nilai mata uang yang dapat menyebabkan } \\
\text { kenaikan harga }\end{array}$ & $\mathrm{R} 4$ & & & & & & & & & & & \\
\hline & & Perubahan kebijakan harga BBM & R5 & & & & & & & & & & & \\
\hline & & Kondisi tanah yang tidak stabil & R6 & & & & & & & & & & & \\
\hline & & \begin{tabular}{|l}
$\begin{array}{l}\text { Gangguan akan adanya aktivitas bongkar muat } \\
\text { barang }\end{array}$ \\
\end{tabular} & R7 & & & & & & & & & & & \\
\hline 3 & $\begin{array}{c}\text { Risiko } \\
\text { Lingkungan }\end{array}$ & \begin{tabular}{|l}
$\begin{array}{l}\text { Instansi/Perusahaan sekitar proyek yang kurang } \\
\text { mendukung }\end{array}$ \\
\end{tabular} & R8 & & & & & & & & & & & \\
\hline & & Pencemaran ekosistem laut dan udara & R9 & & & & & & & & & & & \\
\hline & & Kebisingan suara & $\mathrm{R} 10$ & & & & & & & & & & & \\
\hline & & \begin{tabular}{|l|} 
Adanya double job pada personil sehingga \\
mengurangi fokus personil untuk menyelesaikan satu \\
tugas/pekerjaan
\end{tabular} & R11 & & & & & & & & & & & \\
\hline & Risiko SDM \& & $\begin{array}{|lll|}\begin{array}{l}\text { Perselisihan atau koordinasi yang buruk antar } \\
\text { tenaga kerja }\end{array} & & \\
\end{array}$ & $\mathrm{R} 12$ & & & & & & & & & & & \\
\hline 4 & Manajemen & Keahlian tenaga kerja yang kurang & $\mathrm{R} 13$ & & & & & & & & & & & \\
\hline & & Produktivitas pekerja yang rendah & R14 & & & & & & & & & & & \\
\hline & & Adanya kesalahanpahaman antara stakeholder & R15 & & & & & & & & & & & \\
\hline & & Perubahan struktur organisasi dari pihak owner & R16 & & & & & & & & & & & \\
\hline & & Keterlambatan pembayaran & R17 & & & & & & & & & & & \\
\hline & & Kurangnya dana finansial dari owner & $\mathrm{R} 18$ & & & & & & & & & & & \\
\hline & & Penambahan biaya pengangkutan material & R19 & & & & & & & & & & & \\
\hline & & \begin{tabular}{|l|}
$\begin{array}{l}\text { Penambahan biaya mobilisasi \& demobilisasi alat } \\
\text { baru dikarenakan kesalahan metode kerja }\end{array}$ \\
\end{tabular} & $\mathrm{R} 20$ & & & & & & & & & & & \\
\hline 5 & Risiko Finansial & Penambahan jam kerja/lembur & $\mathrm{R} 21$ & & & & & & & & & & & \\
\hline & & Kehilangan volume material pada pengangkutan & R22 & & & & & & & & & & & \\
\hline & & Kerusakan material pada pengangkutan & $\mathrm{R} 23$ & & & & & & & & & & & \\
\hline & & Kecelakaan yang terjadi saat pengangkutan & R24 & & & & & & & & & & & \\
\hline & & Ketidaktepatan estimasi waktu dan biaya & $\mathrm{R} 25$ & & & & & & & & & & & \\
\hline & & Ketidakpahaman pada dokumen kontrak \& RKS & $\mathrm{R} 26$ & & & & & & & & & & & \\
\hline & & Keterlambatan proses administrasi dan perizinan & R27 & & & & & & & & & & & \\
\hline 6 & Risiko Teknis & $\begin{array}{l}\text { Perubahan desain akıbat perubahan kondisi } \\
\text { lanancan }\end{array}$ & $\mathrm{R} 28$ & & & & & & & & & & & \\
\hline & & Desain yang tidak lengkap & R29 & & & & & & & & & & & \\
\hline
\end{tabular}




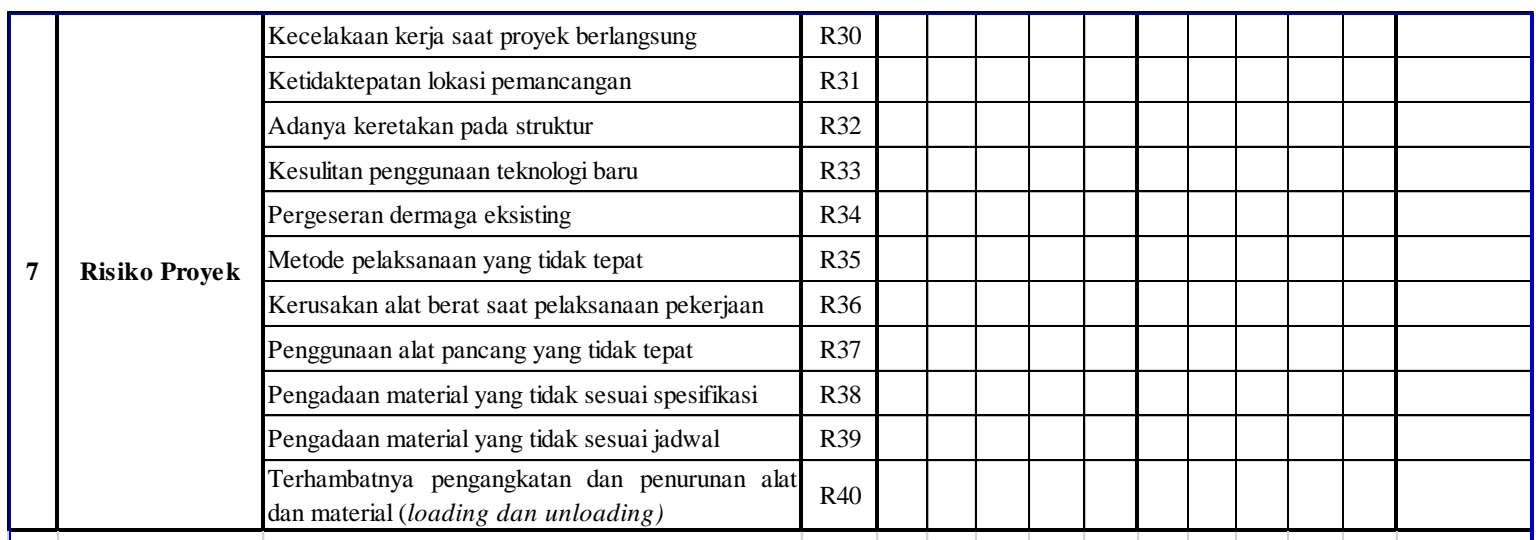

\section{KUESIONER ESSAY}

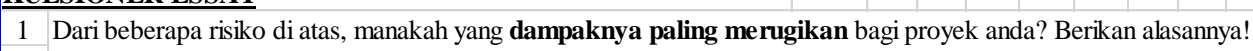

Dan bagaimana cara penanganannya menurut anda? (boleh lebih dari 1 risiko)

Risiko yang paling merugikan :

Alasan :

Cara penanganan :

2 Dari beberapa risiko di atas, manakah risiko yang paling sering terjadi pada proyek anda? Berikan alasannya! Dan bagaimana cara penanganannya menurut anda? (boleh lebih dari 1 risiko)

Risiko yang paling sering terjadi :.

Alasan :

Cara penanganan :

3 Dari beberapa risiko di atas, manakah risiko yang signifikan (paling sering terjadi dan berdampak paling besar) pada proyek anda? Berikan alasannya! Dan bagaimana cara penanganannya menurut anda? (boleh lebih dari 1 risiko)

Risiko yang signifikan :.

Alasan :.

Cara penanganan :

4 Berapa lama maksimal keterlambatan waktu yang diperbolehkan terjadi jika dilihat dari sudut pandang anda selaku kontraktor? (dapat dijawab dalam satuan hari).

Jawaban :

Apa alasan/pertimbangan yang menyebabkan keterlambatan dalam kurun waktu tersebut masih diperbolehkan?

Jawaban :

5 Jika dilihat dari lingkup pekerjaan yang ada, apa kegiatan/pekerjaan yang paling berpotensi mempengaruhi/menyebabkan keterlambatan waktu pada pelaksanaan Perpanjangan Dermaga Log? (boleh lebih dari 1 pekerjaan)

Jawaban :

Alasan :. 
Lampiran $C$

Rekapitulasi Data Pasang Surut (November s.d Fabruari)

\begin{tabular}{|c|c|c|c|c|}
\hline \multicolumn{5}{|c|}{$\begin{array}{l}\text { REKAPITULASI HWL NOVEMBER-FEBRUARI } \\
\text { (KETINGGIAN DALAM METER) }\end{array}$} \\
\hline \multicolumn{5}{|c|}{$06^{\circ} 57^{\prime} 16.20^{\prime \prime} \mathrm{S}-110^{\circ} 25^{\prime} 19.13^{\prime \prime} \mathrm{T}$} \\
\hline \multicolumn{5}{|c|}{ Waktu : G.M.T. +07.00 } \\
\hline \multirow{2}{*}{ Tanggal } & \multicolumn{4}{|c|}{ Bulan } \\
\hline & November & Desember & Januari & Februari \\
\hline 1 & 1.3 & 1.3 & 1.3 & 1.4 \\
\hline 2 & 1.3 & 1.2 & 1.3 & 1.4 \\
\hline 3 & 1.2 & 1.2 & 1.4 & 1.4 \\
\hline 4 & 1.2 & 1.3 & 1.4 & 1.4 \\
\hline 5 & 1.2 & 1.4 & 1.4 & 1.4 \\
\hline 6 & 1.3 & 1.4 & 1.4 & 1.4 \\
\hline 7 & 1.3 & 1.4 & 1.5 & 1.4 \\
\hline 8 & 1.4 & 1.5 & 1.5 & 1.3 \\
\hline 9 & 1.4 & 1.5 & 1.4 & 1.3 \\
\hline 10 & 1.5 & 1.5 & 1.4 & 1.3 \\
\hline 11 & 1.5 & 1.5 & 1.4 & 1.3 \\
\hline 12 & 1.5 & 1.5 & 1.3 & 1.3 \\
\hline 13 & 1.5 & 1.4 & 1.3 & 1.3 \\
\hline 14 & 1.4 & 1.3 & 1.3 & 1.3 \\
\hline 15 & 1.4 & 1.2 & 1.3 & 1.3 \\
\hline 16 & 1.3 & 1.2 & 1.3 & 1.3 \\
\hline 17 & 1.2 & 1.3 & 1.3 & 1.3 \\
\hline 18 & 1.2 & 1.3 & 1.3 & 1.3 \\
\hline 19 & 1.3 & 1.3 & 1.3 & 1.2 \\
\hline 20 & 1.3 & 1.4 & 1.3 & 1.3 \\
\hline 21 & 1.3 & 1.4 & 1.3 & 1.3 \\
\hline 22 & 1.4 & 1.4 & 1.4 & 1.3 \\
\hline 23 & 1.4 & 1.4 & 1.4 & 1.2 \\
\hline 24 & 1.4 & 1.4 & 1.3 & 1.3 \\
\hline 25 & 1.4 & 1.4 & 1.3 & 1.3 \\
\hline 26 & 1.4 & 1.4 & 1.3 & 1.4 \\
\hline 27 & 1.4 & 1.4 & 1.3 & 1.4 \\
\hline 28 & 1.4 & 1.4 & 1.3 & 1.4 \\
\hline 29 & 1.4 & 1.3 & 1.3 & \\
\hline 30 & 1.4 & 1.3 & 1.3 & \\
\hline 31 & $\mathbb{T}$ & 1.3 & 1.4 & \\
\hline
\end{tabular}


Lampiran D

Data Hari Hujan 


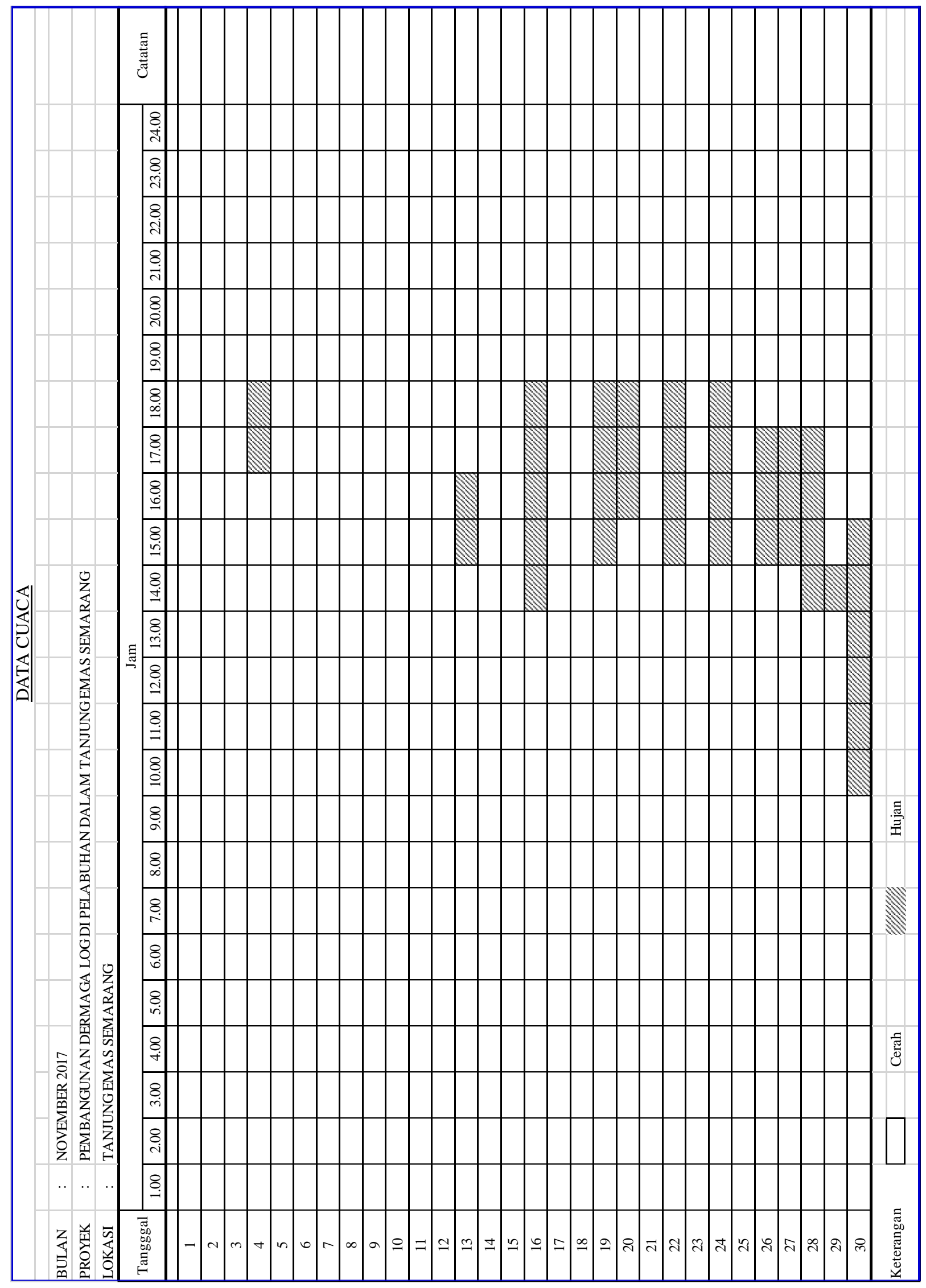




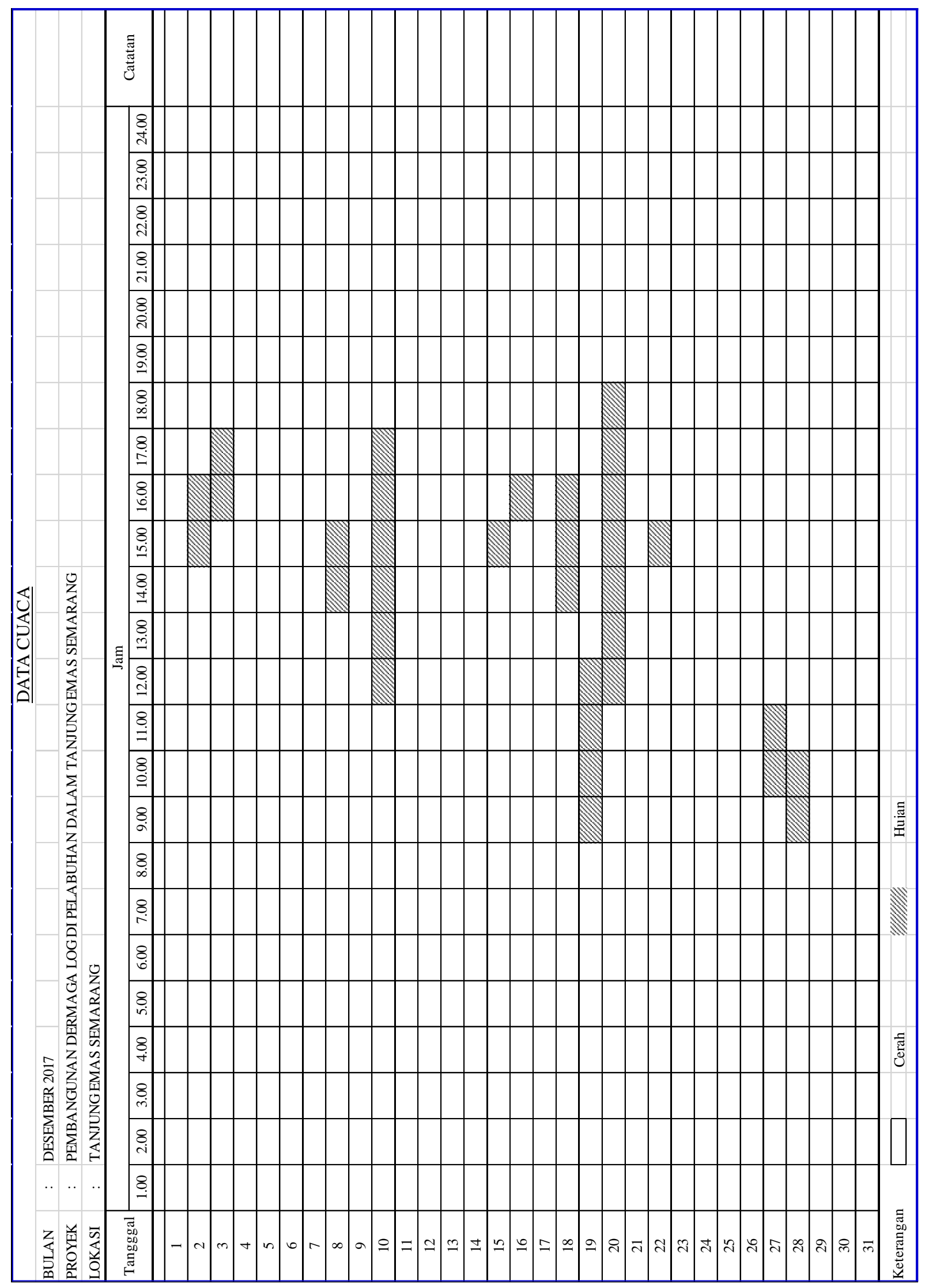




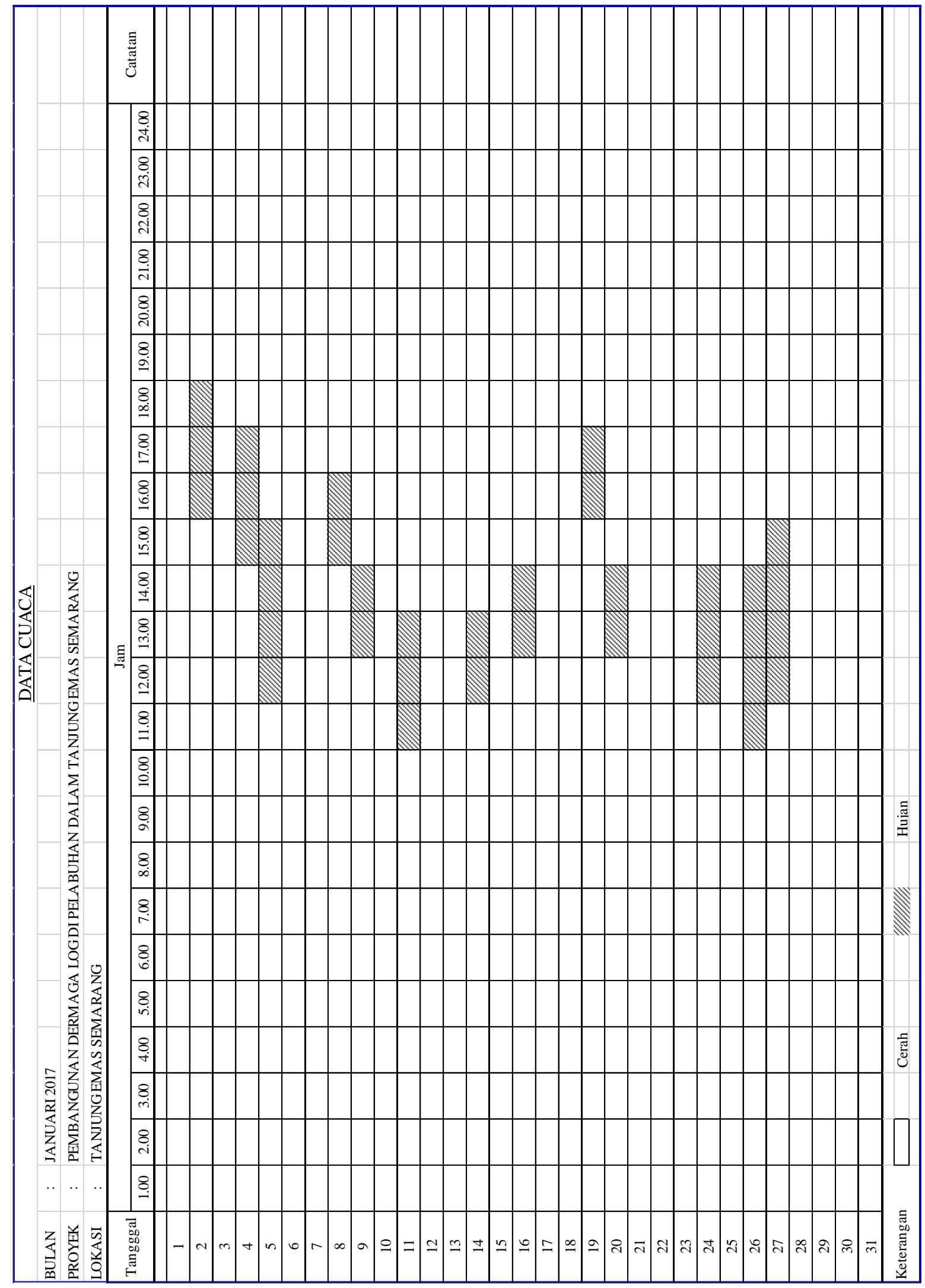




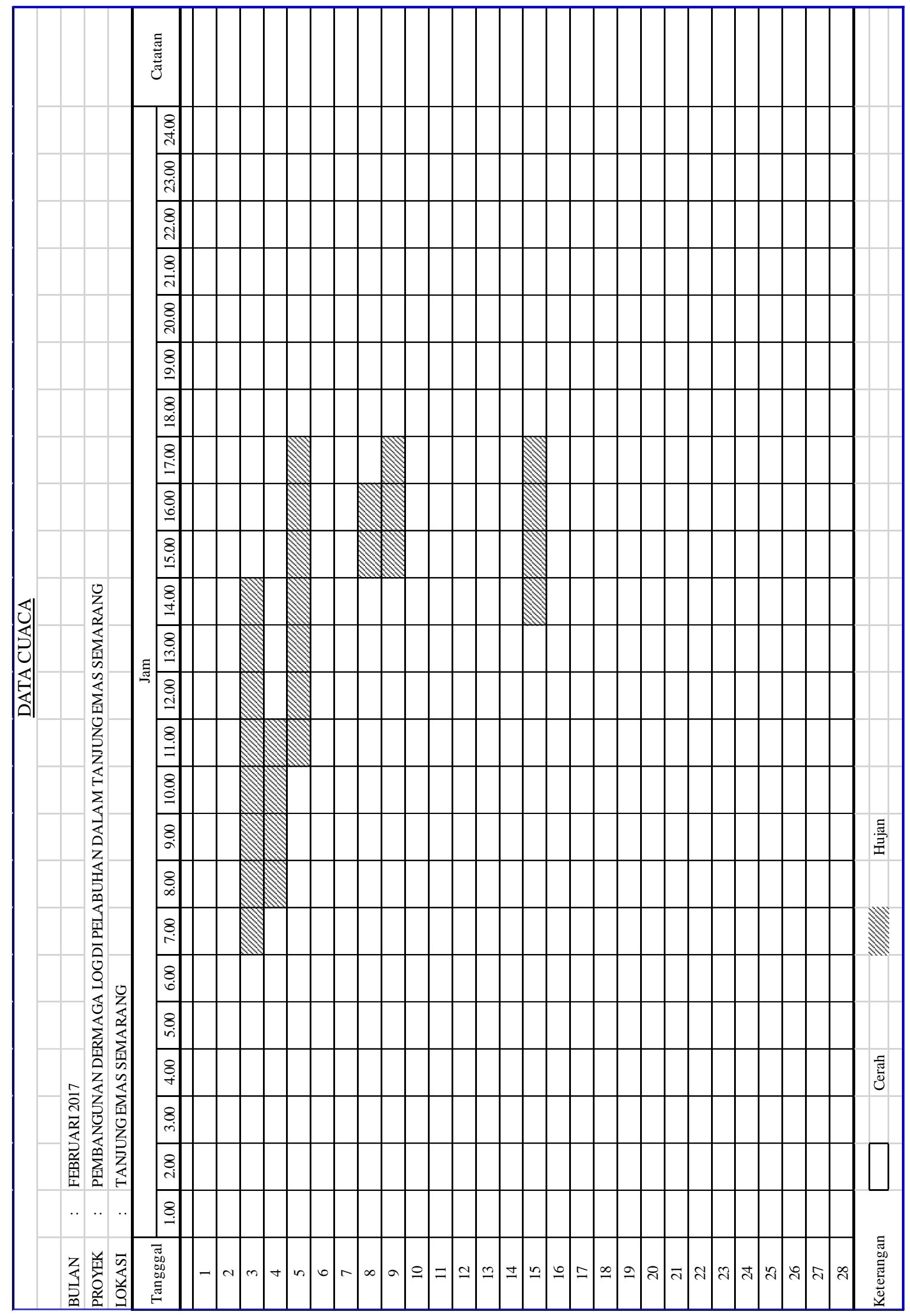




\section{Lampiran E}

Catatan Direksi

Pelaksanaan Perpanjangan Dermaga Log 


\begin{tabular}{|c|c|c|c|}
\hline \multicolumn{4}{|c|}{ CATATAN DIREKSI PROYEK PEMBANGUNAN DERMAGA LOG } \\
\hline \multicolumn{4}{|c|}{ Bulan : November } \\
\hline No & Tanggal & Uraian & Indikasi Risiko \\
\hline 1 & Wednesday, November 1, 2017 & $\begin{array}{l}\text { Kondisi alat pemancangan harus dijaga agar pekerjaan pemancangan tidak } \\
\text { terhenti karena masalah kerusakan alat. }\end{array}$ & \\
\hline 2 & Thursday, November 2, 2017 & $\begin{array}{l}\text { Kontraktor harap melakukan evaluasi terhadap kelurusan tiangpancang terhadap } \\
\text { tepi dermaga lama. }\end{array}$ & \\
\hline 3 & Friday, November 3, 2017 & & \\
\hline 4 & Saturday, November 4, 2017 & $\begin{array}{l}\text { Kontraktor harap dapat berkoordinasi dengan operasional tanjungmas agar lokasi } \\
\text { pekerjaan tidak digunakan untuk parkir kapal tugboat. }\end{array}$ & $\begin{array}{l}\text { gangguan akan adanya } \\
\text { aktivitas bongkar muat }\end{array}$ \\
\hline 5 & Sunday, November 5, 2017 & Harap selalu dijaga koordinat dari tiang pancang & \\
\hline 6 & Monday, November 6, 2017 & Harap untuk pekerja dilengkapi APD & kecelakaan kerja \\
\hline 7 & Tuesday, November 7, 2017 & Kalendering yang dilakukan harus sesuai dengan metode yang ada. & \\
\hline 8 & Wednesday, November 8, 2017 & & \\
\hline 9 & Thursday, November 9, 2017 & $\begin{array}{l}\text { Pemancangan harus dilanjutkan jika saat pelaksanaan kalendering belum } \\
\text { didapatkan nilai yang sesuai syarat yang ada pada RKS. }\end{array}$ & \\
\hline 10 & Friday, November 10, 2017 & $\begin{array}{l}\text { Berdasarkan pengukuran kelurusan tiang pancang terhadap tepi caison, ada } \\
\text { kantilever yang panjangnya akan berbeda dengan rencana mohon kontraktor } \\
\text { segera mengkonsultasikan dengan konsultan dan pelindo. }\end{array}$ & $\begin{array}{l}\text { ketidaktepatan lokasi } \\
\text { pemancangan }\end{array}$ \\
\hline 11 & Saturday, November 11, 2017 & $\begin{array}{l}\text { Pekerjaan sambungan harus disertai dengan pelapisan sambungan dengan bahan } \\
\text { yang disyaratkan di RKS }\end{array}$ & \\
\hline 12 & Sunday, November 12, 2017 & & \\
\hline 13 & Monday, November 13, 2017 & $\begin{array}{l}\text { Pengetesan baja tulangan harus sesuai dengan rks dan semua sample harus sesuai } \\
\text { dengan spesifikasi. }\end{array}$ & \\
\hline 14 & Tuesday, November 14, 2017 & $\begin{array}{l}\text { tim pengukuran harus terus memantau pekerjaan pemancangan agar tidak terjadi } \\
\text { kesalahan koordinat pemancangan. }\end{array}$ & \\
\hline 15 & Wednesday, November 15, 2017 & & \\
\hline 16 & Thursday, November 16, 2017 & $\begin{array}{l}\text { Metode pekerjaan pile cap dan isian beton harus segera diajukan pada direksi } \\
\text { pekerjaan }\end{array}$ & \\
\hline 17 & Friday, November 17, 2017 & $\begin{array}{l}\text { Material besi harap diletakkan di lokasi yang terlindung dari air dan angin laut agar } \\
\text { terhindar dari pengaratan. }\end{array}$ & \\
\hline 18 & Saturday, November 18, 2017 & & \\
\hline 19 & Sunday, November 19, 2017 & $\begin{array}{l}\text { Pekerjaan pengelasan sambungan tiang pancang harus dikerjakan sesuai dengan } \\
\text { spesifikasi penuh setiap bagian yang disambung. }\end{array}$ & \\
\hline 20 & Monday, November 20, 2017 & $\begin{array}{l}\text { Pelapisan sambungan harus menyeluruh untuk melindungi sambungan dari bahaya } \\
\text { karat. }\end{array}$ & \\
\hline 21 & Tuesday, November 21, 2017 & Harap kontraktor segera mengajukan metode precast yang akan dilaksanakan. & \\
\hline 22 & Wednesday, November 22, 2017 & $\begin{array}{l}\text { Kontraktor harap segera mengkonsultasikan mengenai rekonfigurasi tiang } \\
\text { pancang dan pemakaian chemical rebar yang aka digunakan. }\end{array}$ & \\
\hline 23 & Thursday, November 23, 2017 & $\begin{array}{l}\text { Mulai dijadwalkan untuk pelaksanaan tes PDA dan titik mana saja yang akan di } \\
\text { test agar secepatnya dapat diajukan ke direksi pekerjaan. }\end{array}$ & \\
\hline 24 & Friday, November 24, 2017 & & \\
\hline 25 & Saturday, November 25, 2017 & $\begin{array}{l}\text { Pelaksanaan pengecoran harap selalu diperhatikan masalah air laut yang ada di } \\
\text { dalam tiang pancang harus di kuras terlebih dahulu dan digunakan concrete } \\
\text { vibrator untuk memadatkan beton. }\end{array}$ & $\begin{array}{l}\text { metode pelaksanaan yang } \\
\text { tidak tepat }\end{array}$ \\
\hline 26 & Sunday, November 26, 2017 & $\begin{array}{l}\text { Untuk vender harap segera ditentukan suplyernya dan bisa dijdwalkan akan } \\
\text { melakukan test kapan. }\end{array}$ & \\
\hline 27 & Monday, November 27, 2017 & $\begin{array}{l}\text { Pekerjaan perakitan besi tulangan harap dilaksanakan dilokasi yang dapat } \\
\text { terlindungi dari air dan angin laut. }\end{array}$ & \\
\hline 28 & Tuesday, November 28, 2017 & $\begin{array}{l}\text { Sebelum dilaksanakan Pengujian PDA harap dipastikan titik yang akan diuji sesuai } \\
\text { dengan titik pancang yang sudah disetujui direksi Pekerjaan. Selain itu dipastikan } \\
\text { kesiapan alat dan juga semua pihak yang terkait. }\end{array}$ & $\begin{array}{l}\text { keterlambatan administrasi } \\
\text { dan perizinan }\end{array}$ \\
\hline 29 & Wednesday, November 29, 2017 & $\begin{array}{l}\text { Penimbunan material pancang harap tidak menjorok ke arah laut agar tidak } \\
\text { terkena hempasan air laut. }\end{array}$ & \\
\hline 30 & Thursday, November 30, 2017 & $\begin{array}{l}\text { Pengujian Test PDA harap dilaksanakan hingga mendapatkan nilai maksimal dari } \\
\text { Tiang Pancang, tidak hanya mencapai diatas nilai rencana. }\end{array}$ & \\
\hline \multicolumn{4}{|c|}{ Bulan : Desember } \\
\hline No & Tanggal & Uraian & Indikasi Risiko \\
\hline 1 & Friday, December 1, 2017 & $\begin{array}{l}\text { Material tulangan harus diletakkan ditempat yang terlindung dari angin dan } \\
\text { air laut, karena dapat menyebabkan korosi. Besi yang ada dilokasi pekerjaan } \\
\text { minimal harus ditutup terpal semuanya bukan hanya salah satunya. }\end{array}$ & \\
\hline 2 & Saturday, December 2, 2017 & $\begin{array}{l}\text { Hasil Resmi Pengujian PDA harap segera disampaikan kepada Pengawas dan } \\
\text { pihak Owner }\end{array}$ & \\
\hline 3 & Sunday, December 3, 2017 & & \\
\hline 4 & Monday, December 4, 2017 & $\begin{array}{l}\text { Pengelasan sepatu tiang pancang harap dilaksanakan penuh dari ujung ke } \\
\text { ujung tanpa ada bagian yang tertinggal. }\end{array}$ & \\
\hline 5 & Tuesday, December 5, 2017 & $\begin{array}{l}\text { Pekerjaan penimbunan material pembesian harap dilindungi dari hempasan } \\
\text { air laut dan angin laut, karena resiko pengaratan. }\end{array}$ & \\
\hline
\end{tabular}




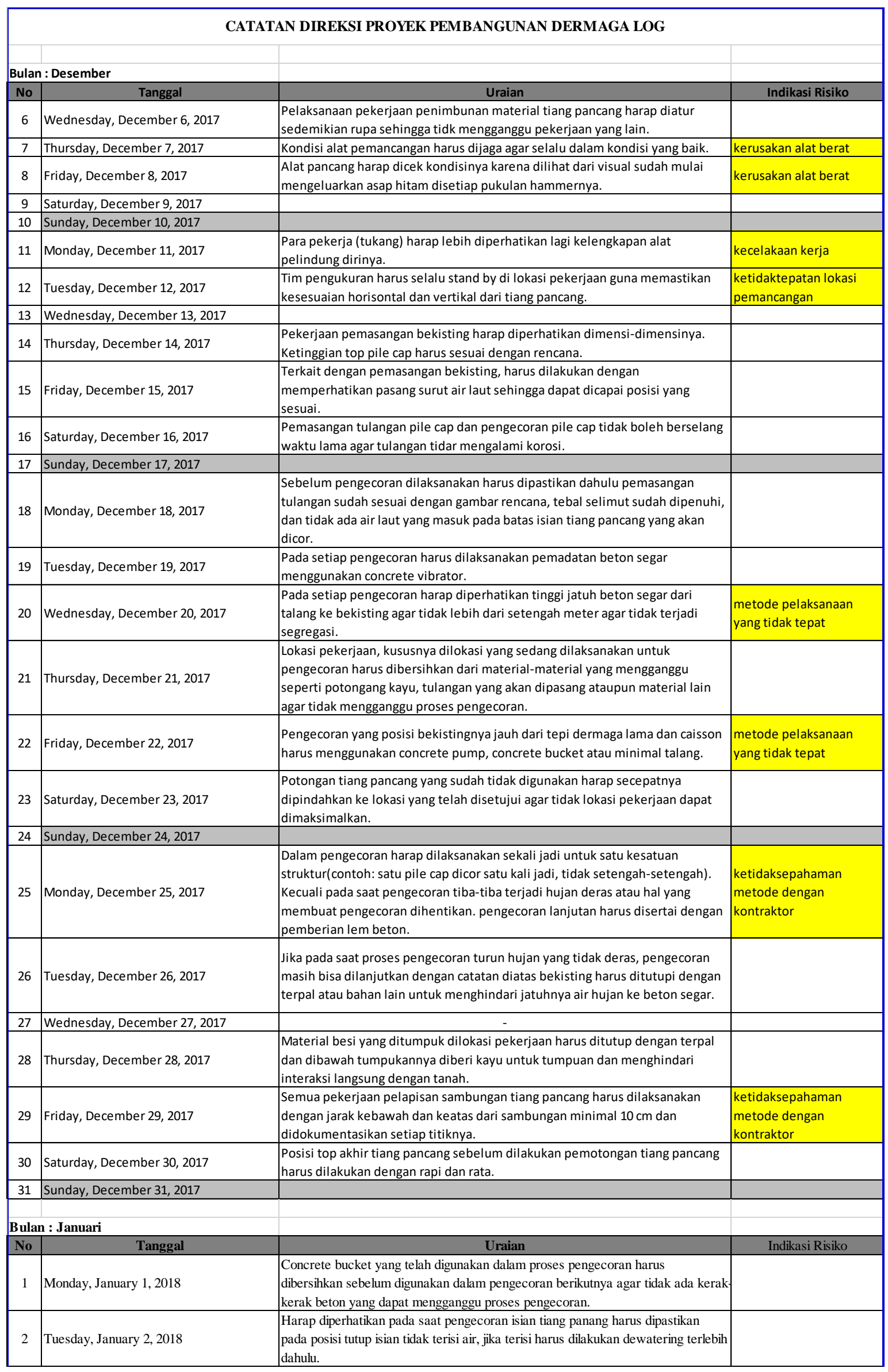




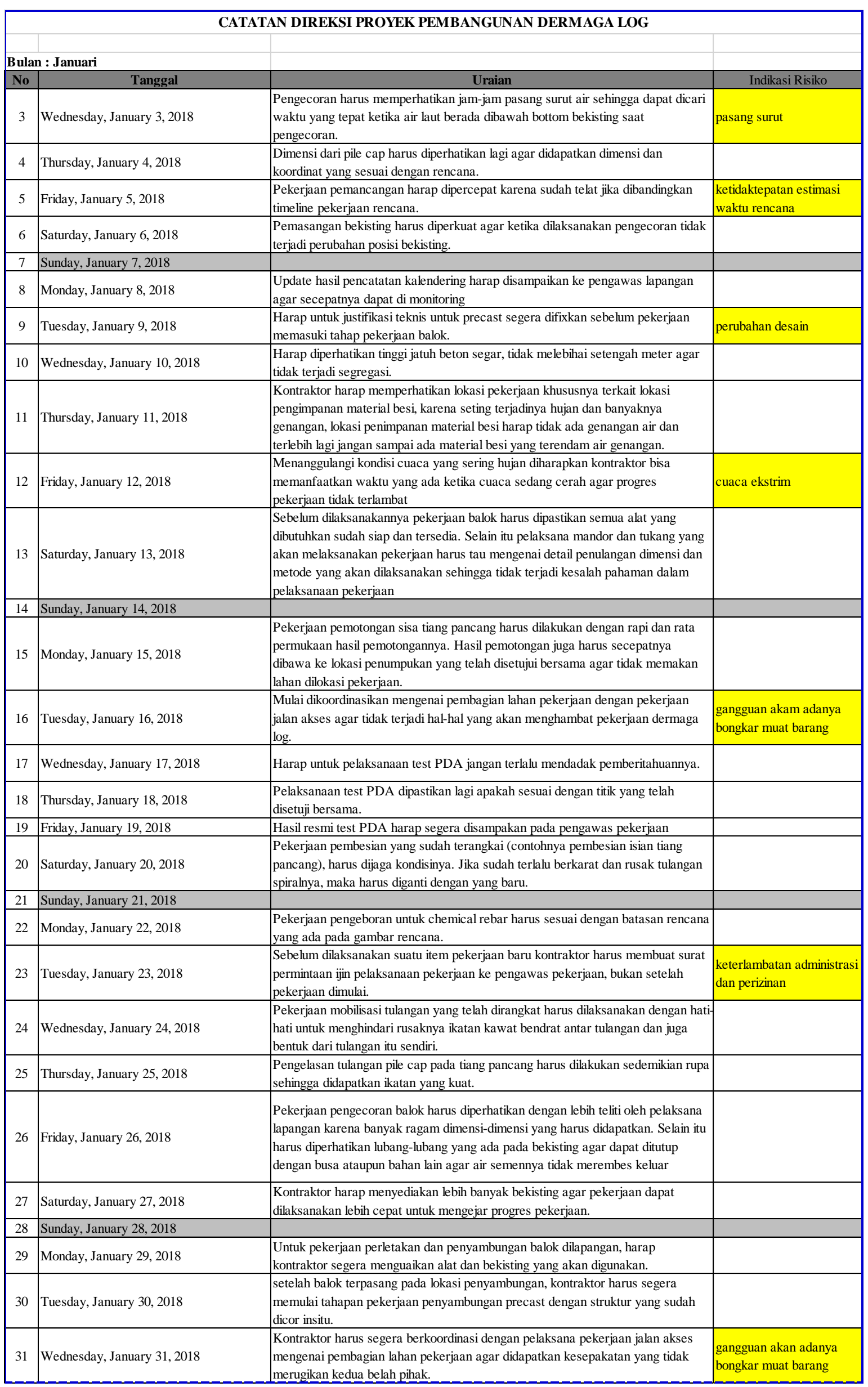




\begin{tabular}{|c|c|c|c|}
\hline \multicolumn{4}{|c|}{ CATATAN DIREKSI PROYEK PEMBANGUNAN DERMAGA LOG } \\
\hline \multicolumn{4}{|c|}{ Bulan : Februari } \\
\hline No & Tanggal & Uraian & Indikasi Risiko \\
\hline 1 & Thursday, February 1, 2018 & $\begin{array}{l}\text { Keseluruhan gambar pelaksanaan yang telah diredesign dengan menggunkan } \\
\text { metode precast harus diserahkan secepatnya kepada pengawas pekerjaan }\end{array}$ & perubahan desain \\
\hline 2 & Friday, February 2, 2018 & $\begin{array}{l}\text { Pekerjaan pemancangan harp bisa dimaksimalkan agar maksimal tanggal } 16 \\
\text { Februari semua tiang telah terpancang dan lokasi pekerjaan dapat digunakan } \\
\text { dengan maksimal. }\end{array}$ & \\
\hline 3 & Saturday, February 3, 2018 & $\begin{array}{c}\text { Sisa pemotongan tiang pancang harap secepatnya dipindahkan ke lokasi } \\
\text { penimbunan yang telah disetujui. }\end{array}$ & \\
\hline 4 & Sunday, February 4, 2018 & & \\
\hline 5 & Monday, February 5, 2018 & $\begin{array}{l}\text { Pekerjaan pengecoran balok harus dipastikan kelurusan vertikal dan horisontal } \\
\text { dari bekisting agar hasil pengecoran bisa sesuai dengan dimensi yang } \\
\text { direncanakan. }\end{array}$ & \\
\hline 6 & Tuesday, February 6, 2018 & $\begin{array}{l}\text { Proses pengangkutan tulangan yang telah dirangkai, dari lokasi pekerjaan ke tepi } \\
\text { dermaga, dan dari tepi dermaga ke tempat pengecoran harus dilakukan dengan } \\
\text { hati-hati. Bentuk tulangan yang telah terangkai tidak boleh terdeformasi, ikatan } \\
\text { kawat bendrat tidak boleh ada yang lepas, jarak antar tulangan harus terjaga. }\end{array}$ & \\
\hline 7 & Wednesday, February 7, 2018 & $\begin{array}{l}\text { Besi tulangan harus dijaga dari korosi karena air laut, besi yang telah berkarat di } \\
\text { selluruh permukaannya tidak boleh lagi digunakan untuk pekerjaan pembetonan. }\end{array}$ & \\
\hline 8 & Thursday, February 8, 2018 & $\begin{array}{l}\text { Besi tulangan yang telah terangkai tidak boleh dibiarkan menunggu proses } \\
\text { pengecoran terlalu lama. Sebelum dilakukan pengecoran harus dipastikan jarak } \\
\text { antar tulangan, tebal selimut beton, dan ikatan kawat bendrat tidak rusak. }\end{array}$ & \\
\hline 9 & Friday, February 9, 2018 & $\begin{array}{l}\text { Bekisting yang telah digunakan jika akan digunakan untuk proses pengecoran lagi, } \\
\text { harus dibersihkan dari kerak-kerak beton yang tertinggal. }\end{array}$ & \\
\hline 10 & Saturday, February 10, 2018 & $\begin{array}{l}\text { Harap dipastikan lagi untuk target minggu depan pemancangan harus sudah } \\
\text { selesai semuanya. Jika dirasa belum memungkinkan kontraktor harap menambah } \\
\text { waktu pekerjaan (lembur) atau menggunakan metode yang lebih efisien waktu. }\end{array}$ & \\
\hline 11 & Sunday, February 11, 2018 & & \\
\hline 12 & Monday, February 12, 2018 & $\begin{array}{l}\text { Besi tulangan terangkai yang terdeformasi harus diperbaiki sebelum dilanjut ke } \\
\text { proses pengecoran. }\end{array}$ & \\
\hline 13 & Tuesday, February 13, 2018 & $\begin{array}{l}\text { Potongan tiang pancang yang sudah tidak digunakan secepatnya dipindahkan ke } \\
\text { lokasi penumpukan }\end{array}$ & \\
\hline 14 & Wednesday, February 14, 2018 & $\begin{array}{l}\text { Penggunaan lahan kerja untuk proses perakitan tulangan dan penumpukan } \\
\text { tulangan yang telah di bentuk harap diperhatikan, jangan dilokasi yang menjadi } \\
\text { akses mobilisasi pekerja dan kendaraan. }\end{array}$ & \\
\hline 15 & Thursday, February 15, 2018 & $\begin{array}{l}\text { Dimensi precast balok harap lebih diperhatikan lagi. Tidak boleh ada dimensi yang } \\
\text { kurang atau lebih, permukaan precast apalagi pada posisi yang akan menumpu pile } \\
\text { cap harus sesuai dengan rencana. }\end{array}$ & \\
\hline 16 & Friday, February 16, 2018 & $\begin{array}{l}\text { Pada saat hujan deras tidak boleh dilaksanakan pengecoran. Karena beresiko } \\
\text { bercampurnya air hujan dan beton segar yang akan menyebabkan berkurangnya } \\
\text { mutu beton. }\end{array}$ & cuaca ekstrim \\
\hline 17 & Saturday, February 17, 2018 & $\begin{array}{l}\text { Pemasangan tulangan harus diperhatikan. Jarak antar tulangan harus sesuai } \\
\text { dengan gambar rencana dan tulangan yang seharusnya bersentuhan harus diikat } \\
\text { dengan kawat bendrat. }\end{array}$ & \\
\hline 18 & Sunday, February 18, 2018 & & \\
\hline 19 & Monday, February 19, 2018 & $\begin{array}{l}\text { Beton yang baru saja dicor harus dicuring selama } 10 \text { hari berdasarkan RKS. } \\
\text { Selama } 2 \text { hari pertama beton tidak boleh kering harus selalu dijaga selalu basah } \\
\text { permukaan dan ditutup karung basah. Selanjutnya selama } 10 \text { hari beton harus } \\
\text { dicuring secara berkala sehari } 3 \text { kali pagi, siang, dan sore. }\end{array}$ & $\begin{array}{l}\text { metode pelaksanaan yang } \\
\text { tidak tepat }\end{array}$ \\
\hline 20 & Tuesday, February 20, 2018 & $\begin{array}{l}\text { Pengecoran pelat, pada penggunaan plastik sebagai alas diantara beton dan } \\
\text { bekisting harap lebih diperhatikan dibagian sudut-sudutnya. Plastik yang terpasang } \\
\text { harus mengakomodasi tercetaknya sudut tepi bawah dari pelat dengan sempurna, } \\
\text { jgan sampai tercetak pelat dengan tepi bawah yang menggelembung dan tidak } \\
\text { sesuai dengan dimensi pelat lantai. }\end{array}$ & \\
\hline 21 & Wednesday, February 21, 2018 & $\begin{array}{l}\text { Diperhatikan lagi tulangan kople untuk balok BC2, tulangan kople harus penuh } \\
\text { dikedua sisi dibagian tumpuan dan lapangan sesuai dengan gambar rencana } \\
\text { precast yang diajukan. }\end{array}$ & \\
\hline 22 & Thursday, February 22, 2018 & $\begin{array}{l}\text { Balok dan pelat precast yang telah tercetak harus difinishing dibagian-bagian yang } \\
\text { bukan merupakan sambungan agar kondisi setelah menyatu nanti tidak } \\
\text { memerlukan banyak proses finishing lagi. }\end{array}$ & \\
\hline 23 & Friday, February 23, 2018 & $\begin{array}{l}\text { Tiang pancang yang telah dipotong dan dipasangi tulangan harus segera dicor. } \\
\text { Apabila setelah pemasangan tulangan pada isian tiang pancang terjadi hujan dan } \\
\text { isian tiang pancang terisi air, harus secepatnya dikuras agar tulangan tidak korosi } \\
\text { karena air laut. }\end{array}$ & \\
\hline 24 & Saturday, February 24, 2018 & & \\
\hline 25 & Sunday, February 25, 2018 & & \\
\hline
\end{tabular}




\section{Lampiran F}

Hasil Monitoring Uji Baja dan Beton 


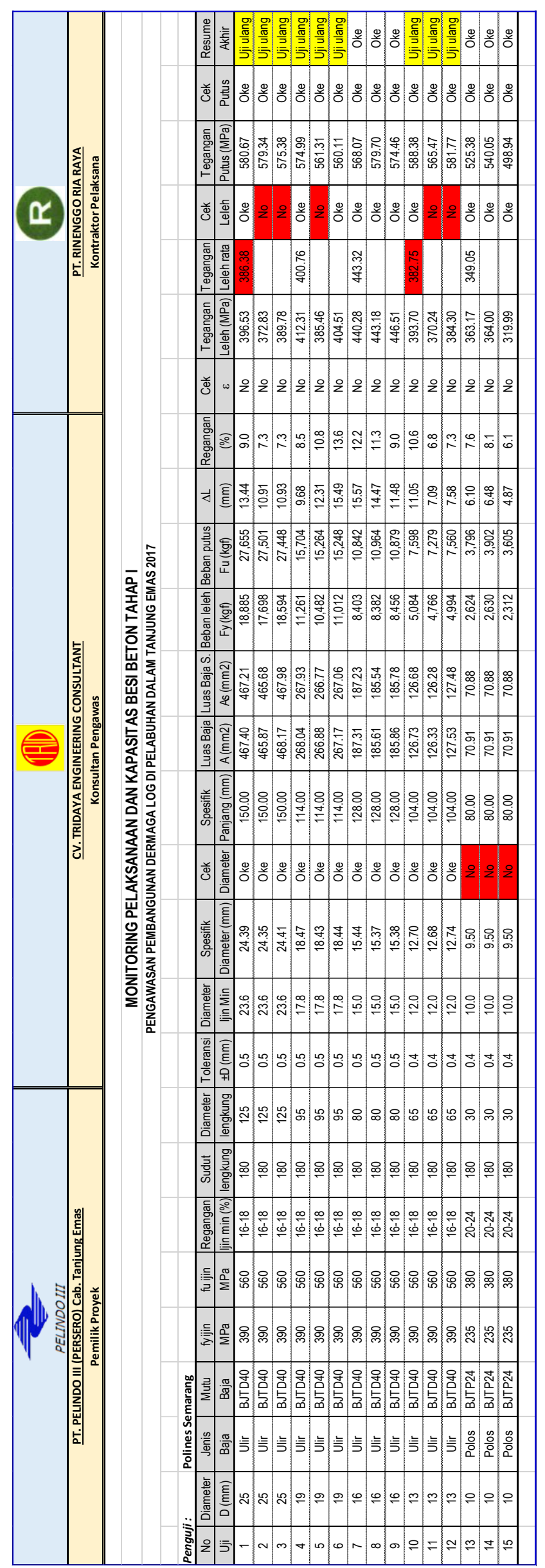




\begin{tabular}{|c|c|c|c|c|c|c|c|c|c|c|c|c|c|c|}
\hline \multicolumn{14}{|c|}{ MONITORING UJI KUAT TEKAN BETON READY MIX } & \multirow{3}{*}{\begin{tabular}{|l} 
Laboratorium \\
\end{tabular}} \\
\hline \multicolumn{14}{|c|}{ PENGAWASAN PEMBANGUNAN DERMAGA LOG DI PELABUHAN DALAM TANJUNG EMAS 2017} & \\
\hline \multirow{2}{*}{ No } & \multirow{2}{*}{$\begin{array}{l}\text { Elemen } \\
\text { Struktur }\end{array}$} & \multirow{2}{*}{\begin{tabular}{|c|} 
Tanggal \\
Pembuatan
\end{tabular}} & \multirow{2}{*}{\begin{tabular}{|c|} 
Tanggal \\
Pengujian \\
\end{tabular}} & \multirow{2}{*}{$\begin{array}{l}\text { Umur } \\
\text { (hari) }\end{array}$} & \multirow{2}{*}{\begin{tabular}{|c|} 
Gaya Tekan \\
(ton) \\
\end{tabular}} & \multirow{2}{*}{\begin{tabular}{|c|} 
Gaya Tekan \\
$(\mathrm{kN})$
\end{tabular}} & Berat Uji & Kokoh Tekan & Kok & Beton 2 & & Kokoh Syarat & Cek Mutu & \\
\hline & & & & & & & $(\mathrm{kg})$ & $(\mathrm{kg} / \mathrm{cm} 2)$ & Silinder & Rasio & Kubus & $\mathrm{K} 350$ & Real>Renc & Pengujian \\
\hline 1 & Beton Isian & $12 / 20 / 2017$ & $1 / 17 / 2018$ & 28 & 66 & 647.46 & 12950 & 373.33 & 373.33 & 1.000 & 449.80 & 350 & Oke & Undip \\
\hline 2 & Beton Isian & $12 / 20 / 2017$ & $1 / 17 / 2018$ & 28 & 69 & 676.89 & 12940 & 390.30 & 390.30 & 1.000 & 470.24 & 350 & Oke & Undip \\
\hline 3 & Beton Isian & $12 / 26 / 2017$ & $1 / 25 / 2018$ & 30 & 55 & 539.55 & 12470 & 311.11 & 306.82 & 0.986 & 369.66 & 350 & Oke & Undip \\
\hline 4 & Beton Isian & $12 / 26 / 2017$ & $1 / 25 / 2018$ & 30 & 61 & 598.41 & 12485 & 345.05 & 340.29 & 0.986 & 409.98 & 350 & Oke & Undip \\
\hline 5 & Beton Isian & $12 / 28 / 2017$ & $1 / 25 / 2018$ & 28 & 55 & 539.55 & 12930 & 311.11 & 311.11 & 1.000 & 374.83 & 350 & Oke & Undip \\
\hline 6 & Beton Isian & $12 / 28 / 2017$ & $1 / 25 / 2018$ & 28 & 61 & 598.41 & 12960 & 345.05 & 345.05 & 1.000 & 415.72 & 350 & Oke & Undip \\
\hline 7 & Beton Isian & $1 / 5 / 2018$ & \begin{tabular}{|l|}
$2 / 2 / 2018$ \\
\end{tabular} & 28 & 58 & 568.98 & 12900 & 328.08 & 328.08 & 1.000 & 395.28 & 350 & Oke & Undip \\
\hline 8 & Beton Isian & $1 / 5 / 2018$ & $2 / 2 / 2018$ & 28 & 59 & 578.79 & 12810 & 333.74 & 333.74 & 1.000 & 402.09 & 350 & Oke & Undip \\
\hline 9 & Beton Isian & $1 / 8 / 2018$ & 2/6/2018 & 29 & 57 & 559.17 & 12830 & 322.42 & 320.81 & 0.995 & 386.52 & 350 & Oke & Undip \\
\hline 10 & Beton Isian & $1 / 8 / 2018$ & \begin{tabular}{|l|}
$2 / 6 / 2018$ \\
\end{tabular} & 29 & 59 & 578.79 & 12900 & 333.74 & 332.07 & 0.995 & 400.08 & 350 & Oke & Undip \\
\hline 11 & Beton Isian & $1 / 10 / 2018$ & $2 / 8 / 2018$ & 29 & 64 & 627.84 & 12730 & 362.02 & 360.21 & 0.995 & 433.99 & 350 & Oke & Undip \\
\hline 12 & Beton Pile & $1 / 10 / 2018$ & $2 / 8 / 2018$ & 29 & 58 & 568.98 & 12830 & 328.08 & 326.44 & 0.995 & 393.30 & 350 & Oke & Undip \\
\hline 13 & Beton Pile & $1 / 11 / 2018$ & \begin{tabular}{|l|}
$2 / 8 / 2018$ \\
\end{tabular} & 28 & 60 & 588.60 & 12790 & 339.39 & 339.39 & 1.000 & 408.91 & 350 & Oke & Undip \\
\hline 14 & Beton Pile & $1 / 11 / 2018$ & $2 / 8 / 2018$ & 28 & 57 & 559.17 & 12760 & 322.42 & 322.42 & 1.000 & 388.46 & 350 & Oke & Undip \\
\hline 15 & Beton Pile & $1 / 12 / 2018$ & $2 / 8 / 2018$ & 27 & 68 & 667.08 & 12810 & 384.65 & 388.57 & 1.010 & 468.16 & 350 & Oke & Undip \\
\hline 16 & Beton Pile & $1 / 12 / 2018$ & 2/8/2018 & 27 & 76 & 745.56 & 12690 & 429.90 & 434.29 & 1.010 & 523.24 & 350 & Oke & Undip \\
\hline 17 & Beton Pile & $1 / 13 / 2018$ & $2 / 15 / 2018$ & 33 & 83 & 814.23 & 12550 & 469.49 & 453.06 & 0.965 & 545.86 & 350 & Oke & Undip \\
\hline 18 & Beton Pile & $1 / 13 / 2018$ & $2 / 15 / 2018$ & 33 & 64 & 627.84 & 12640 & 362.02 & 349.35 & 0.965 & 420.90 & 350 & Oke & Undip \\
\hline 19 & Beton Pile & $1 / 15 / 2018$ & $2 / 15 / 2018$ & 31 & 66 & 647.46 & 12690 & 373.33 & 366.02 & 0.980 & 440.98 & 350 & Oke & Undip \\
\hline 20 & Beton Pile & $1 / 15 / 2018$ & 2/15/2018 & 31 & 55 & 539.55 & 12530 & 311.11 & 305.01 & 0.980 & 367.49 & 350 & Oke & Undip \\
\hline 21 & Beton Pile & $1 / 17 / 2018$ & $2 / 15 / 2018$ & 29 & 50 & 490.50 & 12810 & 282.83 & 281.41 & 0.995 & 339.05 & 350 & No & Undip \\
\hline 22 & Beton Pile & $1 / 17 / 2018$ & $2 / 15 / 2018$ & 29 & 67 & 657.27 & 12790 & 378.99 & 377.09 & 0.995 & 454.33 & 350 & Oke & Undip \\
\hline 23 & Beton Pile & $1 / 18 / 2018$ & $2 / 15 / 2018$ & 28 & 63 & 618.03 & 12810 & 356.36 & 356.36 & 1.000 & 429.35 & 350 & Oke & Undip \\
\hline 24 & Beton Pile & $1 / 18 / 2018$ & $2 / 15 / 2018$ & 28 & 64 & 627.84 & 12900 & 362.02 & 362.02 & 1.000 & 436.17 & 350 & Oke & Undip \\
\hline 25 & Beton Pile & $1 / 19 / 2018$ & $2 / 20 / 2018$ & 32 & 75 & 735.75 & 12990 & 424.24 & 411.94 & 0.971 & 496.31 & 350 & Oke & Undip \\
\hline 26 & Beton Pile & $1 / 19 / 2018$ & $2 / 20 / 2018$ & 32 & 78 & 765.18 & 12890 & 441.21 & 428.42 & 0.971 & 516.17 & 350 & Oke & Undip \\
\hline 27 & Beton Pile & $1 / 22 / 2018$ & $2 / 20 / 2018$ & 29 & 52 & 510.12 & 12780 & 294.14 & 292.67 & 0.995 & 352.62 & 350 & Oke & Undip \\
\hline 28 & Beton Pile & $1 / 22 / 2018$ & $2 / 20 / 2018$ & 29 & 57 & 559.17 & 12570 & 322.42 & 320.81 & 0.995 & 386.52 & 350 & Oke & Undip \\
\hline 29 & Beton Pile & $1 / 22 / 2018$ & $2 / 20 / 2018$ & 29 & 52 & 510.12 & 12780 & 294.14 & 292.67 & 0.995 & 352.62 & 350 & Oke & Undip \\
\hline 30 & Beton Pile & $1 / 22 / 2018$ & $2 / 20 / 2018$ & 29 & 57 & 559.17 & 12570 & 322.42 & 320.81 & 0.995 & 386.52 & 350 & Oke & Undip \\
\hline 31 & Beton Pile & $1 / 23 / 2018$ & $2 / 20 / 2018$ & 28 & 66 & 647.46 & 12980 & 373.33 & 373.33 & 1.000 & 449.80 & 350 & Oke & Undip \\
\hline 32 & Beton Pile & $1 / 23 / 2018$ & $2 / 20 / 2018$ & 28 & 62 & 608.22 & 12970 & 350.71 & 350.71 & 1.000 & 422.54 & 350 & Oke & Undip \\
\hline 33 & Beton Pile & $1 / 24 / 2018$ & $2 / 23 / 2018$ & 30 & 68 & 667.08 & 12670 & 384.65 & 379.34 & 0.986 & 457.03 & 350 & Oke & Undip \\
\hline 34 & Beton Pile & $1 / 24 / 2018$ & $2 / 23 / 2018$ & 30 & 64 & 627.84 & 12690 & 362.02 & 357.02 & 0.986 & 430.15 & 350 & Oke & Undip \\
\hline 35 & Beton Pile & $1 / 25 / 2018$ & $2 / 23 / 2018$ & 29 & 71 & 696.51 & 12590 & 401.62 & 399.61 & 0.995 & 481.46 & 350 & Oke & Undip \\
\hline 36 & Beton Pile & $1 / 25 / 2018$ & $2 / 23 / 2018$ & 29 & 58 & 568.98 & 12590 & 328.08 & 326.44 & 0.995 & 393.30 & 350 & Oke & Undip \\
\hline 37 & Beton Pile & $1 / 26 / 2018$ & $2 / 26 / 2018$ & 31 & 57 & 559.17 & 12590 & 322.42 & 316.10 & 0.980 & 380.85 & 350 & Oke & Undip \\
\hline 38 & Beton Pile & $1 / 26 / 2018$ & 2/26/2018 & 31 & 76 & 745.56 & 12540 & 429.90 & 421.47 & 0.980 & 507.80 & 350 & Oke & Undip \\
\hline 39 & Beton Pile & $1 / 28 / 2018$ & $2 / 26 / 2018$ & 29 & 64 & 627.84 & 12410 & 362.02 & 360.21 & 0.995 & 433.99 & 350 & Oke & Undip \\
\hline 40 & Beton Pile & $1 / 28 / 2018$ & $2 / 26 / 2018$ & 29 & 67 & 657.27 & 12430 & 378.99 & 377.09 & 0.995 & 454.33 & 350 & Oke & Undip \\
\hline 41 & Beton Pile & $1 / 29 / 2018$ & $2 / 26 / 2018$ & 28 & 72 & 706.32 & 12515 & 407.27 & 407.27 & 1.000 & 490.69 & 350 & Oke & Undip \\
\hline 42 & Beton Pile & $1 / 29 / 2018$ & $2 / 26 / 2018$ & 28 & 55 & 539.55 & 12455 & 311.11 & 311.11 & 1.000 & 374.83 & 350 & Oke & Undip \\
\hline 43 & Beton Pile & $1 / 30 / 2018$ & $2 / 26 / 2018$ & 27 & 77 & 755.37 & 12550 & 435.56 & 440.00 & 1.010 & 530.12 & 350 & Oke & Undip \\
\hline 44 & Beton Pile & $1 / 30 / 2018$ & $2 / 26 / 2018$ & 27 & 78 & 765.18 & 12630 & 441.21 & 445.71 & 1.010 & 537.00 & 350 & Oke & Undip \\
\hline 45 & Beton Pile & $2 / 1 / 2018$ & \begin{tabular}{|l|}
$3 / 2 / 2018$ \\
\end{tabular} & 29 & 60 & 588.60 & 12620 & 339.39 & 337.70 & 0.995 & 406.86 & 350 & Oke & Undip \\
\hline 46 & Beton Balo & $2 / 1 / 2018$ & $3 / 2 / 2018$ & 29 & 57 & 559.17 & 12600 & 322.42 & 320.81 & 0.995 & 386.52 & 350 & Oke & Undip \\
\hline 47 & Beton Balo & $2 / 2 / 2018$ & 3/2/2018 & 28 & 58 & 568.98 & 12630 & 328.08 & 328.08 & 1.000 & 395.28 & 350 & Oke & Undip \\
\hline 48 & Beton Balo & $2 / 2 / 2018$ & $3 / 2 / 2018$ & 28 & 56 & 549.36 & 12650 & 316.77 & 316.77 & 1.000 & 381.65 & 350 & Oke & Undip \\
\hline 49 & Beton Balo & $2 / 3 / 2018$ & $3 / 6 / 2018$ & 31 & 68 & 667.08 & 12600 & 384.65 & 377.11 & 0.980 & 454.35 & 350 & Oke & Undip \\
\hline 50 & Beton Balo & $2 / 3 / 2018$ & $3 / 6 / 2018$ & 31 & 75 & 735.75 & 12680 & 424.24 & 415.93 & 0.980 & 501.12 & 350 & Oke & Undip \\
\hline 51 & Beton Balo & $2 / 6 / 2018$ & $3 / 5 / 2018$ & 27 & 55 & 539.55 & 12960 & 311.11 & 314.29 & 1.010 & 378.66 & 350 & Oke & Undip \\
\hline 52 & Beton Balo & $2 / 6 / 2018$ & $3 / 5 / 2018$ & 27 & 69 & 676.89 & 12750 & 390.30 & 394.29 & 1.010 & 475.04 & 350 & Oke & Undip \\
\hline 53 & Beton Balo & $2 / 7 / 2018$ & $3 / 6 / 2018$ & 27 & 57 & 559.17 & 12670 & 322.42 & 325.71 & 1.010 & 392.43 & 350 & Oke & Undip \\
\hline 54 & Beton Balo & $2 / 7 / 2018$ & $3 / 6 / 2018$ & 27 & 58 & 568.98 & 12480 & 328.08 & 331.43 & 1.010 & 399.31 & 350 & Oke & Undip \\
\hline 55 & Beton Balo & $2 / 7 / 2018$ & 3/8/2018 & 29 & 70 & 686.70 & 12880 & 395.96 & 393.98 & 0.995 & 474.67 & 350 & Oke & Undip \\
\hline 56 & Beton Balo & $2 / 7 / 2018$ & $3 / 8 / 2018$ & 29 & 85 & 833.85 & 12980 & 480.81 & 478.40 & 0.995 & 576.39 & 350 & Oke & Undip \\
\hline 57 & Beton Balo & $2 / 8 / 2018$ & $3 / 16 / 2018$ & 36 & 75 & 735.75 & 12640 & 424.24 & 402.13 & 0.948 & 484.50 & 350 & Oke & Undip \\
\hline 58 & Beton Balo & $2 / 8 / 2018$ & $3 / 16 / 2018$ & 36 & 63 & 618.03 & 12600 & 356.36 & 337.79 & 0.948 & 406.98 & 350 & Oke & Undip \\
\hline 59 & Beton Balo & $2 / 9 / 2018$ & $3 / 16 / 2018$ & 35 & 54 & 529.74 & 12690 & 305.45 & 290.91 & 0.952 & 350.50 & 350 & Oke & Undip \\
\hline 60 & Beton Balo & $2 / 9 / 2018$ & $3 / 16 / 2018$ & 35 & 67 & 657.27 & 12670 & 378.99 & 360.95 & 0.952 & 434.88 & 350 & Oke & Undip \\
\hline
\end{tabular}




\begin{tabular}{|c|c|c|c|c|c|c|c|c|c|c|c|c|c|c|}
\hline \multicolumn{14}{|c|}{ MONITORING UJI KUAT TEKAN BETON READY MIX } & \\
\hline \multicolumn{14}{|c|}{ PENGAWASAN PEMBANGUNAN DERMAGA LOG DI PELABUHAN DALAM TANJUNG EMAS 2017} & \\
\hline \multirow{2}{*}{ No } & \multirow{2}{*}{$\begin{array}{l}\text { Elemen } \\
\text { Struktur }\end{array}$} & \multirow{2}{*}{\begin{tabular}{|c|} 
Tanggal \\
Pembuatan
\end{tabular}} & \multirow{2}{*}{\begin{tabular}{|c|} 
Tanggal \\
Pengujian \\
\end{tabular}} & \multirow{2}{*}{$\begin{array}{l}\text { Umur } \\
\text { (hari) }\end{array}$} & \multirow{2}{*}{\begin{tabular}{|c|} 
Gaya Tekan \\
(ton) \\
\end{tabular}} & \multirow{2}{*}{\begin{tabular}{|c|} 
Gaya Tekan \\
$(\mathrm{kN})$ \\
\end{tabular}} & \multirow{2}{*}{\begin{tabular}{|c|} 
Berat Uji \\
$(\mathrm{kg})$
\end{tabular}} & \multirow{2}{*}{\begin{tabular}{|c|} 
Kokoh Tekan \\
(kg/cm2) \\
\end{tabular}} & \multicolumn{3}{|c|}{ Kokoh Beton 28 hari } & \multirow{2}{*}{\begin{tabular}{|c|} 
Kokoh Syarat \\
K350 \\
\end{tabular}} & \multirow{2}{*}{\begin{tabular}{|c|} 
Cek Mutu \\
Real>Renc \\
\end{tabular}} & Laboratorium \\
\hline & & & & & & & & & Silinder & Rasio & Kubus & & & Pengujian \\
\hline 61 & Beton Balo & $2 / 12 / 2018$ & $3 / 16 / 2018$ & 32 & 68 & 667.08 & 12630 & 384.65 & 373.49 & 0.971 & 449.99 & 350 & Oke & Undip \\
\hline 62 & Beton Balo & $2 / 12 / 2018$ & $3 / 16 / 2018$ & 32 & 60 & 588.60 & 12630 & 339.39 & 329.55 & 0.971 & 397.05 & 350 & Oke & Undip \\
\hline 63 & Beton Balo & $2 / 13 / 2018$ & $3 / 16 / 2018$ & 31 & 77 & 755.37 & 12650 & 435.56 & 427.02 & 0.980 & 514.48 & 350 & Oke & Undip \\
\hline 64 & Beton Balo & $2 / 13 / 2018$ & $3 / 16 / 2018$ & 31 & 81 & 794.61 & 12610 & 458.18 & 449.20 & 0.980 & 541.21 & 350 & Oke & Undip \\
\hline 65 & Beton Balo & $2 / 14 / 2018$ & $3 / 16 / 2018$ & 30 & 55 & 539.55 & 12610 & 311.11 & 306.82 & 0.986 & 369.66 & 350 & Oke & Undip \\
\hline 66 & Beton Balo & $2 / 14 / 2018$ & $3 / 16 / 2018$ & 30 & 57 & 559.17 & 12600 & 322.42 & 317.97 & 0.986 & 383.10 & 350 & Oke & Undip \\
\hline 67 & Beton Balo & $2 / 15 / 2018$ & $3 / 16 / 2018$ & 29 & 65 & 637.65 & 12640 & 367.68 & 365.84 & 0.995 & 440.77 & 350 & Oke & Undip \\
\hline 68 & Beton Balo & $2 / 15 / 2018$ & $3 / 16 / 2018$ & 29 & 60 & 588.60 & 12600 & 339.39 & 337.70 & 0.995 & 406.86 & 350 & Oke & Undip \\
\hline 69 & Beton Balo & $2 / 16 / 2018$ & $3 / 20 / 2018$ & 32 & 74 & 725.94 & 12900 & 418.59 & 406.45 & 0.971 & 489.70 & 350 & Oke & Undip \\
\hline 70 & Beton Balo & $2 / 16 / 2018$ & $3 / 20 / 2018$ & 32 & 70 & 686.70 & 12870 & 395.96 & 384.48 & 0.971 & 463.23 & 350 & Oke & Undip \\
\hline 71 & Beton Balo & $2 / 17 / 2018$ & $3 / 20 / 2018$ & 31 & 75 & 735.75 & 12850 & 424.24 & 415.93 & 0.980 & 501.12 & 350 & Oke & Undip \\
\hline 72 & Beton Balo & $2 / 17 / 2018$ & $3 / 20 / 2018$ & 31 & 82 & 804.42 & 12830 & 463.84 & 454.75 & 0.980 & 547.89 & 350 & Oke & Undip \\
\hline 73 & Beton Balo & $2 / 19 / 2018$ & $3 / 20 / 2018$ & 29 & 77 & 755.37 & 12790 & 435.56 & 433.38 & 0.995 & 522.14 & 350 & Oke & Undip \\
\hline 74 & Beton Balo & $2 / 19 / 2018$ & $3 / 20 / 2018$ & 29 & 66 & 647.46 & 12930 & 373.33 & 371.47 & 0.995 & 447.55 & 350 & Oke & Undip \\
\hline 75 & Beton Balo & $2 / 20 / 2018$ & $3 / 20 / 2018$ & 28 & 77 & 755.37 & 12910 & 435.56 & 435.56 & 1.000 & 524.77 & 350 & Oke & Undip \\
\hline 76 & Beton Balo & $2 / 20 / 2018$ & $3 / 20 / 2018$ & 28 & 69 & 676.89 & 12800 & 390.30 & 390.30 & 1.000 & 470.24 & 350 & Oke & Undip \\
\hline 77 & Beton Balo & $2 / 21 / 2018$ & $3 / 23 / 2018$ & 30 & 70 & 686.70 & 12830 & 395.96 & 390.49 & 0.986 & 470.47 & 350 & Oke & Undip \\
\hline 78 & Beton Balo & $2 / 21 / 2018$ & $3 / 23 / 2018$ & 30 & 64 & 627.84 & 12760 & 362.02 & 357.02 & 0.986 & 430.15 & 350 & Oke & Undip \\
\hline 79 & Beton Balo & $2 / 22 / 2018$ & $3 / 23 / 2018$ & 29 & 67 & 657.27 & 12810 & 378.99 & 377.09 & 0.995 & 454.33 & 350 & Oke & Undip \\
\hline 80 & Beton Balo & $2 / 22 / 2018$ & $3 / 23 / 2018$ & 29 & 69 & 676.89 & 12850 & 390.30 & 388.35 & 0.995 & 467.89 & 350 & Oke & Undip \\
\hline 81 & Beton Balo & $2 / 23 / 2018$ & $3 / 23 / 2018$ & 28 & 51 & 500.31 & 12730 & 288.48 & 288.48 & 1.000 & 347.57 & 350 & No & Undip \\
\hline 82 & Beton Balo & $2 / 23 / 2018$ & $3 / 23 / 2018$ & 28 & 56 & 549.36 & 12750 & 316.77 & 316.77 & 1.000 & 381.65 & 350 & Oke & Undip \\
\hline 83 & Beton Balo & $2 / 26 / 2018$ & $3 / 28 / 2018$ & 30 & 57 & 559.17 & 12990 & 322.42 & 317.97 & 0.986 & 383.10 & 350 & Oke & Undip \\
\hline 84 & Beton Balo & $2 / 26 / 2018$ & $3 / 28 / 2018$ & 30 & 58 & 568.98 & 12970 & 328.08 & 323.55 & 0.986 & 389.82 & 350 & Oke & Undip \\
\hline 85 & Beton Balo & $2 / 27 / 2018$ & $3 / 27 / 2018$ & 28 & 44 & 431.64 & 12740 & 248.89 & 248.89 & 1.000 & 299.87 & 350 & No & Undip \\
\hline 86 & Beton Balo & $2 / 27 / 2018$ & $3 / 27 / 2018$ & 28 & 61 & 598.41 & 12760 & 345.05 & 345.05 & 1.000 & 415.72 & 350 & Oke & Undip \\
\hline 87 & Beton Balo & $3 / 1 / 2018$ & $4 / 2 / 2018$ & 32 & 65 & 637.65 & 12750 & 367.68 & 357.01 & 0.971 & 430.14 & 350 & Oke & Undip \\
\hline 88 & Beton Balo & $3 / 1 / 2018$ & $4 / 2 / 2018$ & 32 & 69 & 676.89 & 12770 & 390.30 & 378.98 & 0.971 & 456.61 & 350 & Oke & Undip \\
\hline 89 & Beton Balo & $3 / 2 / 2018$ & $4 / 2 / 2018$ & 31 & 61 & 598.41 & 12800 & 345.05 & 338.29 & 0.980 & 407.58 & 350 & Oke & Undip \\
\hline 90 & Beton Balo & $3 / 2 / 2018$ & $4 / 2 / 2018$ & 31 & 60 & 588.60 & 12750 & 339.39 & 332.74 & 0.980 & 400.89 & 350 & Oke & Undip \\
\hline 91 & Beton Balo & $3 / 3 / 2018$ & $4 / 2 / 2018$ & 30 & 71 & 696.51 & 12700 & 401.62 & 396.07 & 0.986 & 477.20 & 350 & Oke & Undip \\
\hline 92 & Beton Balo & $3 / 3 / 2018$ & $4 / 2 / 2018$ & 30 & 70 & 686.70 & 12780 & 395.96 & 390.49 & 0.986 & 470.47 & 350 & Oke & Undip \\
\hline 93 & Beton Balo & $3 / 5 / 2018$ & $4 / 2 / 2018$ & 28 & 61 & 598.41 & 12770 & 345.05 & 345.05 & 1.000 & 415.72 & 350 & Oke & Undip \\
\hline 94 & Beton Balo & $3 / 5 / 2018$ & $4 / 2 / 2018$ & 28 & 64 & 627.84 & 12710 & 362.02 & 362.02 & 1.000 & 436.17 & 350 & Oke & Undip \\
\hline 95 & Beton Balo & $3 / 6 / 2018$ & $4 / 2 / 2018$ & 27 & 66 & 647.46 & 12730 & 373.33 & 377.14 & 1.010 & 454.39 & 350 & Oke & Undip \\
\hline 96 & Beton Balo & $3 / 6 / 2018$ & $4 / 2 / 2018$ & 27 & 57 & 559.17 & 12720 & 322.42 & 325.71 & 1.010 & 392.43 & 350 & Oke & Undip \\
\hline 97 & Beton Balo & $3 / 7 / 2018$ & $4 / 5 / 2018$ & 29 & 59 & 578.79 & 12830 & 333.74 & 332.07 & 0.995 & 400.08 & 350 & Oke & Undip \\
\hline 98 & Beton Balo & $3 / 7 / 2018$ & $4 / 5 / 2018$ & 29 & 70 & 686.70 & 12920 & 395.96 & 393.98 & 0.995 & 474.67 & 350 & Oke & Undip \\
\hline 99 & Beton Balo & $3 / 12 / 2018$ & $4 / 9 / 2018$ & 28 & 58 & 568.98 & 12800 & 328.08 & 328.08 & 1.000 & 395.28 & 350 & Oke & Undip \\
\hline 100 & Beton Balo & $3 / 12 / 2018$ & $4 / 9 / 2018$ & 28 & 57 & 559.17 & 12750 & 322.42 & 322.42 & 1.000 & 388.46 & 350 & Oke & Undip \\
\hline 101 & Beton Balo & $3 / 14 / 2018$ & $4 / 11 / 2018$ & 28 & 70 & 686.70 & 12760 & 395.96 & 395.96 & 1.000 & 477.06 & 350 & Oke & Undip \\
\hline 102 & Beton Balo & $3 / 14 / 2018$ & $4 / 11 / 2018$ & 28 & 71 & 696.51 & 12770 & 401.62 & 401.62 & 1.000 & 483.87 & 350 & Oke & Undip \\
\hline 103 & Beton Balo & $3 / 15 / 2018$ & 4/11/2018 & 27 & 50 & 490.50 & 12730 & 282.83 & 285.71 & 1.010 & 344.23 & 350 & No & Undip \\
\hline 104 & Beton Balo & $3 / 15 / 2018$ & $4 / 11 / 2018$ & 27 & 48 & 470.88 & 12760 & 271.52 & 274.29 & 1.010 & 330.46 & 350 & No & Undip \\
\hline 105 & Beton Balo & $3 / 16 / 2018$ & $4 / 13 / 2018$ & 28 & 80 & 784.80 & 12830 & 452.53 & 452.53 & 1.000 & 545.21 & 350 & Oke & Undip \\
\hline 106 & Beton Balo & $3 / 16 / 2018$ & $4 / 13 / 2018$ & 28 & 85 & 833.85 & 12850 & 480.81 & 480.81 & 1.000 & 579.29 & 350 & Oke & Undip \\
\hline & & & & & & & & & & & & & & \\
\hline & & & & & & & & & & & Uji Sampe & Lab Undip & & \\
\hline & & & & & & & & & & & 1. Sampel & lolos & 101 & \\
\hline & & & & & & & & & & & 2. Sampel & gagal & 5 & \\
\hline & & & & & & & & & & & Total sam & & 106 & \\
\hline
\end{tabular}


Lampiran G

Kurva S Proyek Akhir Minggu Ke-25

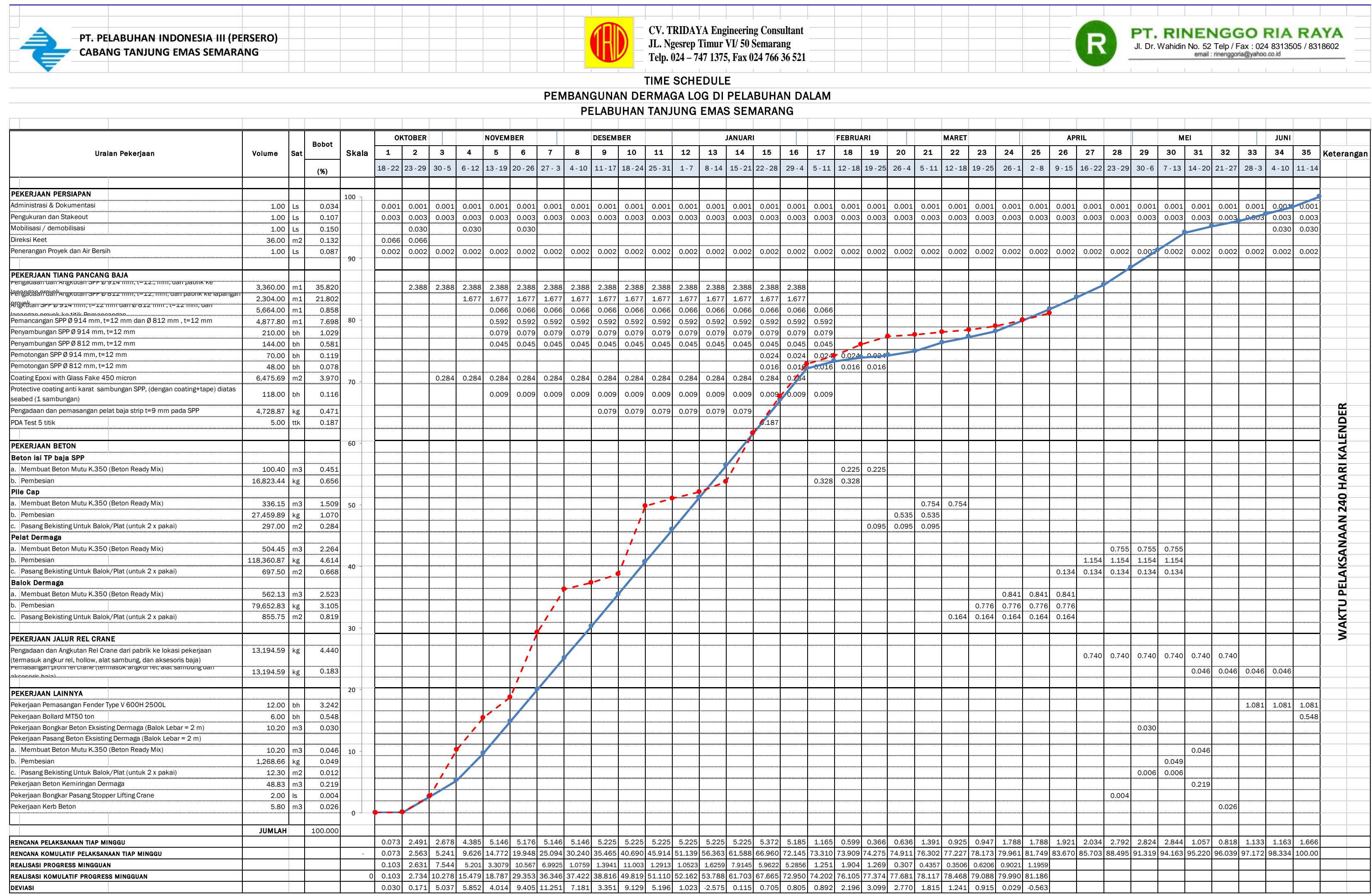

